Discussion Paper No. 09-085

A Framework to Enforce Anti-Predation Rules

Kai Hüschelrath and Jürgen Weigand

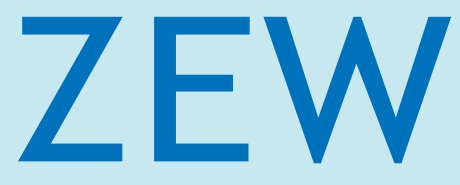

Zentrum für Europäische Wirtschaftsforschung $\mathrm{GmbH}$

Centre for European

Economic Research 
Discussion Paper No. 09-085

\section{A Framework to Enforce Anti-Predation Rules}

Kai Hüschelrath and Jürgen Weigand

Download this ZEW Discussion Paper from our ftp server:

ftp://ftp.zew.de/pub/zew-docs/dp/dp09085.pdf

Die Discussion Papers dienen einer möglichst schnellen Verbreitung von neueren Forschungsarbeiten des ZEW. Die Beiträge liegen in alleiniger Verantwortung der Autoren und stellen nicht notwendigerweise die Meinung des ZEW dar.

Discussion Papers are intended to make results of ZEW research promptly available to other economists in order to encourage discussion and suggestions for revisions. The authors are solely responsible for the contents which do not necessarily represent the opinion of the ZEW. 


\section{Non-technical summary}

The major interest of antitrust law and economics with respect to predation strategies has been largely twofold. On the one hand, there has been a lively discussion on the question whether predation can basically be a rational strategy for an incumbent facing an entry threat. On the other hand, research has focused on the problem of how an antitrust authority should detect predation strategies and especially distinguish such abuses from socially desirable, procompetitive behaviour. However, compared to other areas of antitrust policy such as hard core cartel enforcement or merger control, surprisingly little research has been devoted to the subsequent third stage in antitrust analysis: intervention. This stage acknowledges the necessity of appropriate detection rules for efficient antitrust enforcement, but it uses these insights to answer the complementary question of how these rules should be linked to punishment with a pecuniary fine and/or the imposition of behavioural remedies.

Against this background, the paper aims at developing a framework to enforce anti-predation rules that explicitly takes the intervention stage into account. Following a characterisation and rationalisation of predation, the welfare effects of predation are studied. Given the key finding that predation can be a rational business strategy with negative implications on overall welfare, research with respect to the detection of predation is reviewed. However, given the fact that detecting is a necessary but not sufficient condition for 'enforcing', the intervention options against predators are analyzed subsequently. The analysis differentiates between a no rule approach, an ex post rule of reason and an ex ante per se rule. It was shown that no policy option dominates the others and that the welfare optimal policy response depends on several industry and market characteristics such as the level of the incumbency advantages, the level of the gains of entry for society or the specifics of antitrust enforcement in the respective jurisdiction. Subsequently, the key insights of the analysis are incorporated into the development of a framework to enforce anti-predation rules which aims at increasing the deterrence effect of predation strategies without biasing the fundamentally important incentives of firms for procompetitive price decreases. 


\section{Das Wichtigste in Kürze}

Die rechtsökonomische Forschung hat sich im Bezug auf die Setzung von Kampfpreisen in der Vergangenheit auf insbesondere zwei Schwerpunkte konzentriert. Auf der einen Seite fand eine lebhafte Diskussion der Fragestellung statt, ob Kampfpreissetzung überhaupt eine rationale Strategie für ein alteingesessenes Unternehmen sein kann, das sich einem Markteintritt eines anderen Unternehmens ausgesetzt sieht. Auf der anderen Seite hat sich die Forschung auf die Frage konzentriert, wie eine Wettbewerbsbehörde den Begriff der Kampfpreissetzung definieren sollte und wie sie entsprechende Verstöße aufdecken kann. Im Vergleich zu anderen Bereichen der Wettbewerbspolitik wie der Kartellverfolgung oder der Fusionskontrolle erfolgte jedoch keine detaillierte Untersuchung der Frage, wie eine Wettbewerbsbehörde auf die Feststellung eines kampfpreissetzenden Unternehmens sanktionsseitig reagieren sollte. Die Beantwortung dieser Frage geht von einer ökonomisch korrekten Aufdeckung von Kampfpreisstrategien aus und untersucht komplementär dazu, wie solche Regeln verbunden werden sollten mit der Verhängung von Geldstrafen oder verhaltensbezogenen Auflagen.

Vor diesem Hintergrund verfolgt das vorliegende Papier das Ziel, ein Untersuchungsschema zur Verfolgung von Kampfpreisstrategien zu entwickeln, das explizit die Stufe der wettbewerbspolitischen Sanktionen bzw. Eingriffe mit einbezieht. Um dieses Ziel zu erreichen, erfolgt zunächst eine grundlegende Charakterisierung von Kampfpreisstrategien, gefolgt von einer Betrachtung der Wohlfahrtseffekte solcher Strategien. Basierend auf der Feststellung, dass Kampfpreissetzung eine durchaus rationale Strategie von alteingesessenen Unternehmen darstellen kann, werden Möglichkeiten der Aufdeckung von Kampfpreissetzungen zusammenfassend dargestellt. Die darauf aufbauende Analyse der Eingriffsmöglichkeiten einer Wettbewerbsbehörde differenziert dann zwischen einem Ansatz ohne jedweden Eingriff, einem ex post Ansatz und einem ex ante Ansatz. Es wird gezeigt, dass kein Ansatz insofern dominant ist, als er immer zu einer wohlfahrtsoptimalen Lösung führt, sondern dass die optimale wettbewerbspolitische Vorgehensweise abhängt von verschiedenen Industrie- bzw. Markteigenschaften wie der Größe des Vorsprungs alteingesessener Unternehmen, dem gesellschaftlichen Nutzen des Markteintritts eines Wettbewerbers sowie der Stärke und Bedeutung der Wettbewerbsbehörde in der entsprechenden Jurisdiktion. Alle diese Erkenntnisse fließen dann ein in die Ableitung des Untersuchungsschemas für die Behandlung von Kampfpreisstrategien welches das zentrale Ziel verfolgt, die Glaubwürdigkeit der Verfolgung von Kampfpreisstrategien zu erhöhen ohne gleichzeitig die Anreize für wettbewerbsrechtlich unbedenkliche Preissenkungen negativ zu beeinflussen. 


\title{
A FRAMEWORK TO ENFORCE ANTI-PREDATION RULES
}

\author{
Kai Hüschelrath * \\ ZEW Centre for European Economic Research \\ WHU Otto Beisheim School of Management \\ Jürgen Weigand ${ }^{\#}$ \\ WHU Otto Beisheim School of Management
}

\begin{abstract}
The paper develops a framework to enforce anti-predation rules that explicitly takes the intervention stage into account. In particular, it is proposed to improve predation enforcement by focusing on two channels: refining the current regime, and amending it. With respect to the refinement of the current predation enforcement regime, criteria for the imposition of optimal gain- or harm-based fines are derived in order to sharpen the deterrent effect of predation enforcement. However, given the very low probability of conviction for predators a policy proposal solely based on an increase in the fines for detected and convicted predators might be too weak to significantly amplify the deterrence effect in particular and to improve predation enforcement in general. As a consequence, the introduction of a pre-screening approach is proposed, which aims at identifying industries in which entry is difficult but desirable and a predation strategy might be a suitable instrument for an incumbent to fight such occasional entry attempts. In those industries, it is advisable to reduce the high standard of proof in predation enforcement, as its basic justification - the danger to create a negative deterrence effect - is significantly reduced.
\end{abstract}

Keywords Competition policy, monopolisation, predation, enforcement, sanctions, screening

JEL Class K21, L41

* Researcher, ZEW Centre for European Economic Research, Department for Industrial Economics and International Management, L7,1, 68161 Mannheim, Germany and Assistant Professor of Industrial Organization and Competitive Strategy, WHU Otto Beisheim School of Management, Burgplatz 2, 56179 Vallendar, Germany, E-Mail: hueschelrath@zew.de. We would like to thank Peter Møllgaard for valuable comments. The usual disclaimer applies.

\# Professor of Economics, WHU Otto Beisheim School of Management, Burgplatz 2, 56179 Vallendar, Germany, E-Mail: jweigand@whu.edu. 


\section{Introduction}

The major interest of antitrust law and economics with respect to predation strategies has been largely twofold. On the one hand, there has been a lively discussion on the question whether predation can basically be a rational strategy for an incumbent facing an entry threat. On the other hand, research has focused on the problem of how an antitrust authority should detect predation strategies and especially distinguish such abuses from socially desirable, procompetitive behaviour. However, compared to other areas of antitrust policy such as hard core cartel enforcement or merger control, surprisingly little research has been devoted to the subsequent third stage in antitrust analysis: intervention. This stage acknowledges the necessity of appropriate detection rules for efficient antitrust enforcement, but it uses these insights to answer the complementary question of how these rules should be linked to punishment with a pecuniary fine and/or the imposition of behavioural remedies.

Thoughtful answers to the intervention question are important from at least two perspectives. First, from a theoretical perspective, the development and implementation of an integrated approach of antitrust analysis - which aims at creating and maintaining an efficient deterrence effect - demands a clear perspective on how predators will be punished. Second, from a practical perspective, the last couple of years have not only seen a significant increase in predation cases in Europe, but gave rise to a new type of predation cases. Although at first glance, cases such as Napp $^{1}$, Lufthansa ${ }^{2}$, Wanadoo ${ }^{3}$ and Aberdeen Journal ${ }^{4}$ look like fairly typical predation cases, a closer look reveals that all these cases have one new characteristic in common: A predator was found guilty and was punished with a pecuniary fine and/or behavioural remedies. In the past, such successful predation cases have been the exception rather than the rule. This is particularly true for the United States where the last three decades went by without a major conviction of a single predator and commentators largely agree that especially the high enforcement standards created by Brooke Group 5 as well as the defeat of the Department of Justice in $A M R^{6}$ cast doubt that predation enforcement will get going (again) in the near future.

Against this background, the paper aims at developing a framework to enforce anti-predation rules. Such a framework does not only focus on the well-investigated stages of the rationality and detection of predation but additionally has to take the intervention stage into account. In order to reach this aim, the paper is structured into eight sections. The second section aims at characterising what should be understood by the term predation. In the third section, the literature on whether predation can be a rational (i.e., profit-maximising) strategy for an incumbent facing an entry threat is reviewed. Based on affirmative theoretical and empirical research, the fourth section focuses on assessing the welfare effects of predation strategies. Given the finding that predation strategies typically cause negative welfare effects, the fifth section explores how to detect predation strategies, followed by an assessment of the intervention stage in the sixth section. The insights of sections two to six are subsequently incorporated into the development of a framework to enforce anti-predation rules which aims at increasing the deterrence effect of predation strategies without biasing the fundamentally important incentives of firms for procompetitive price decreases. Section eight concludes the paper by summarising the key results.

Napp Pharmaceutical Holdings Ltd. and Subsidiaries v. Director General of Fair Trading, CA98/2/2001 (2001).

Beschluss in dem Verwaltungsverfahren gegen Deutsche Lufthansa AG, Köln, B 9-144/01 (2002).

3 COMP/38.233 - Wanadoo Interactive (2003).

4 Predation by Aberdeen Journal Ltd., CA98/5/2001 (2002).

5 Brooke Group Ltd. v. Brown \& Williamson Tobacco Corp., 509 U.S. 209 (1993).

6 United States v. AMR Corp., 140 F Supp 2d 1141, 1194 (2001). 


\section{Characterising Predation}

A fairly large number of definitions of predation exist. Cabral and Riordan 7 , for example, define an action as 'predatory' if "a different action would increase the likelihood that rivals remain viable and ... the different action would be more profitable under the counterfactual hypothesis that the rival's viability were unaffected". According to Farrell and Katz ${ }^{8}$, predatory behaviour can be schematically thought of as occurring in two phases: a predation phase and a recoupment phase. In the first phase, the predator tenders a product that offers 'too much value' to consumers (e.g., the price is too low, the quality is too high, or the product is too innovative) and thus weakens rivals. In the second phase, the recoupment phase, the predatory firm takes advantage of the weakened rival and reduces the consumer value of its products to a level below the competitive one.

Based on this initial characterisation, Figure 1 clarifies the general business concept of a predation strategy by plotting the profits of the incumbent over time. Initially, a market in which a single incumbent sets the profit-maximising (monopoly) price is assumed. The incumbent gains a so-called excess profit, which is defined as the difference between the monopoly profit $\pi$ Mono and the duopoly profit $\pi{ }^{\text {Duo }}$. At point $t^{\text {entry }}$, a rival firm enters the market. If the incumbent accommodates the rival in the market, both firms would realise $\pi^{\text {Duo }}$. In a Cournot equilibrium, the profits of both firms are assumed to be positive ${ }^{9}$ but of different size as long as both firms are not symmetrical in terms of their cost structures and production capacities. If the incumbent accommodates the entrant, it would lose its excess profit.

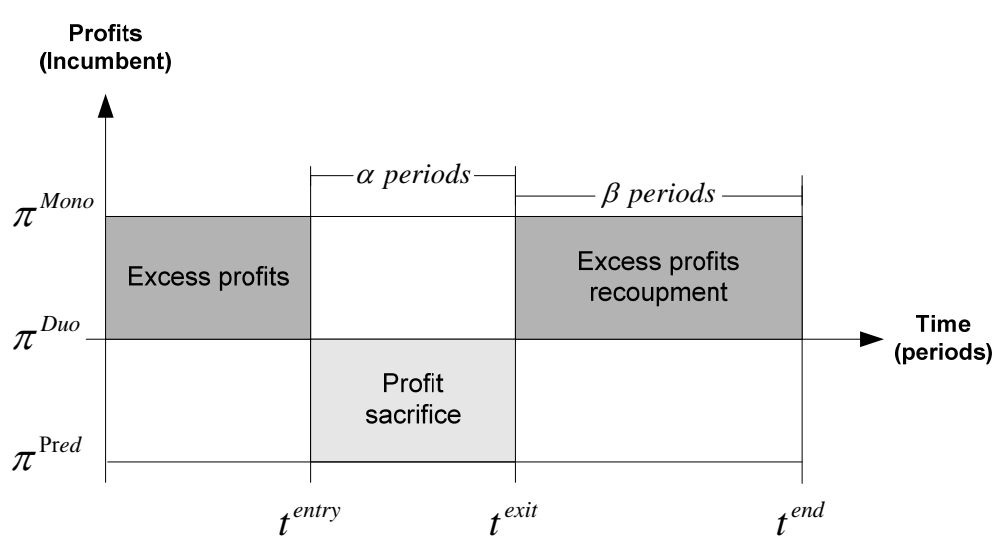

Fig. 1. Predation investment in future excess profits

Besides entry accommodation, the incumbent might think about the possibility of lowering the price, raising the quality, etc., by such an amount that the entrant makes losses and is forced to exit the market at point $t^{\text {exit }}$. Although the incumbent has to sacrifice profits during the predation period, he might regain its old monopoly position and the corresponding monopoly profit $\pi$ Mono until the market ends or another rival firm enters the market.

Following the set-up in Figure 1, the profitability of the predation investment depends on especially five factors: (1) the level of losses in the predation period ( $\left.\pi^{\text {Duo }}-\pi^{\text {Pred }}\right)$; (2) the level

7 Luis Cabral \& Michael Riordan, "The Learning Curve, Predation, Antitrust, and Welfare", Journal of Industrial Economics 45, (1997): 155-169 at 160.

8 Joseph Farrell \& Michael Katz, "Competition or Predation? Schumpeterian Rivalry in Network Markets", Working Paper, University of California, Berkeley, 2001, at 2.

9 In technical terms, this assumption secures that there is room for an entrant in a competitive Nash equilibrium and that only the incumbent's pricing policy turns this entry value negative. See Louis Phlips, Competition Policy: A Game-Theoretic Perspective, Cambridge University Press, Cambridge, 1995, 230-244. 
of excess profits after the exit of the entrant $\left(\pi^{\text {Mono }}-\pi^{\text {Duo }}\right)$; (3) the number of predation periods $\alpha$; (4) the number of periods after the exit of the entrant $\beta$ and (5) the discounting factor of future profits $\delta$. The specifics of these key success factors of predation strategies are determined by numerous market characteristics. Consider for example barriers to entry. The overall profit in the post-predation phase depends on the level of the excess profits and the length of the postpredation phase. The length of the post-predation phase depends on the possibilities (and profitability) of other firms to enter the market (e.g., extent of barriers to [re-]entry, [sunk] entry costs). As a consequence, the rationality of predation critically depends on the extent of barriers to entry respective entry costs. ${ }^{10}$

Another example focuses on the perceived strength of the entrant. The profitability of the predation strategy depends on the length of the predation period $\alpha$, simply because it is one factor that determines the costs of a predation strategy. If the incumbent assumes that the entrant is strong - probably because it has a financially viable parent company - the predation period would likely be too long (or generally unsuccessful) to make predation a profitable strategy for the incumbent. As a consequence, the rationality of predation critically depends on the incumbent's perception of the entrant's strength.

Recent economic research has focused mainly on factors (2) and (4), namely assessing ways by which the predator can recoup its losses sacrificed in the predation period. The most straightforward answer is that it can achieve changes in market structure by forcing exit so that it can regain excess profits and strengthen its dominant market position. ${ }^{11}$ Another channel to reach the necessary recoupment are changes in the nature of competition; for example, the predator obtains a tough reputation and can deter future entry in the same or adjacent markets. ${ }^{12} \mathrm{~A}$ third possibility to recoup the losses of the predation period is through changes in the nature of demand; for example, by (additional) consumers switching from the market-leaving entrant to the predator. ${ }^{13}$

\section{Rationalising Predation}

Based on this characterisation of predation deriving two basic conditions for rational predation is straightforward. First, the use of such a strategy must expect a positive net present value of the investment, meaning that the benefits gained in period two must exceed the cost stemming from period one (effectiveness condition). Second, in the decision situation at hand there must be no superior alternative strategy, meaning that no strategy is available which could reach the same profit level with less cost burden or a higher profit level with the same cost burden (efficiency condition). If one of the two conditions is not fulfilled, predation becomes an irrational strategy and the observed price cuts must be explained differently.

Focusing on the efficiency question first, one frequently cited argument for the irrationality of predation strategies is that in any situation in which predation would be profitable, it is not profit-maximising for a long-run profit-maximising firm. "A dominant firm would be better off acquiring its competitors, colluding with them to fix monopoly prices, or simply accommodating and sharing the profits of oligopoly". ${ }^{14}$ Without trying to prove the theoretical correctness of this

10 For a more complete roundup, see Stephen Martin, Industrial Economics, Prentice Hall, Englewood Cliffs, 1994, 452-468.

11 Hemphill shows that the incumbent might be willing to engage in costly predation even if the total profit is negative, especially in situations in which the entrant is more efficient than the incumbent and the latter has to fear a continuous erosion of its own market share. See Scott Hemphill, "The Role of Recoupment in Predatory Pricing Analyses”, Stanford Law Review 53, (2001): 1581-1612.

12 In other words, recoupment must not necessarily take place in the same market as the sacrifice.

13 See Frontier Economics, "How Low Can You Go? Minimising the Pain of Price Wars", Strategy Bulletin, London, (2002).

14 Adriaan Ten Kate \& Gunnar Niels, "On the Rationality of Predation: The Debate between Chicago and PostChicago", Antitrust Bulletin 47, (2002): 1-24 at 3. 
proposition (which appears to be challenging at least in a multi-market context), it is obviously based on the presumption that acquisition, collusion or accommodation are suitable and reachable strategic answers to market entry for an incumbent. With respect to mergers and acquisitions it is obvious that such a presumption is critical as soon as some kind of merger control procedure is implemented. Such investigations would foreclose (or at least endanger) the success of strategic mergers, especially in cases where aggressive maverick firms are the target. Collusion as an alternative strategy is often confronted with severe agreement and stability problems; and accommodating might generally be a dangerous strategy in the long run, especially if the entrant is more efficient than the incumbent. ${ }^{15}$ Moreover, colluding and accommodating can hardly be suitable general strategies for an incumbent in response to entry, as such conduct would reduce the entry risk of potential entrants and therefore would create some kind of 'reputation for faintness' ${ }^{16}$ Consequently, even in the case that other strategies are more efficient in a certain situation, predation can be some kind of second-best way of maintaining a monopoly position. Posner ${ }^{17}$ fortifies this argumentation by remarking that a firm might prefer predation over strategic acquisitions, as predation is more difficult to detect by the antitrust authorities.

The effectiveness question is the general focus of most research on predation and produced a multitude of arguments in favour of or against its rationality. Starting with the simple delineation of predation in two periods, the arguments of the opponents are based on two simple, interrelated arguments. First, the incumbent's losses in the first period are severe because of its high market share. ${ }^{18}$ Second, the expected gains in the second period are low, in fact, too low to outweigh the severe losses realised in the first period. Some scholars find it implausible, for instance, that the predator can foreclose the market effectively for new entrants in the post-predation period, especially if new entrants can buy the equipment of the market-leaving prey. A further argument states that investors have a profit-driven incentive to help efficient victims with credits to survive the predation period. As a rational predator can foresee this, the predation strategy becomes unprofitable and therefore irrational.

It is the merit of game-theoretic research to have investigated the correctness of such arguments in a rigid analytical framework. The fundamental results show that predatory actions could indeed be optimal strategies in a world of incomplete or asymmetric information. The socalled models of financial market predation address the question of why investors should not have an incentive to help efficient victims to survive the predation period. One answer is that, due to information asymmetries in efficient capital markets, investors do not know exactly the efficiency of the entrant and the entrant has incentives to covey a "misleading optimistic impression of its ability to survive". ${ }^{19}$ Given this incomplete information combined with opportunism, investors will not provide capital or at best a risk premium which increases the costs of the entrant.

15 However, as Ashiya shows, the incumbent might welcome weak entrants in the market in order to block other more threatening potential entrants. See Masahiro Ashiya, "Weak Entrants are Welcome", International Journal of Industrial Organization 18, (2000): 975-984.

16 Following Stigler and Salant, Switzer and Reynolds, firms in an oligopoly might have limited possibilities of eliminating rivals by mergers, since the costs of such concentration are mainly carried by the acquiring firm, while the gains are spread to all firms in the industry. See George Stigler, "Monopoly and Oligopoly by Merger", American Economic Review 40, (1950): 23-34 and Stephen Salant, Sheldon Switzer \& Robert Reynolds, "Losses due to Merger: The Effects of an Exogenous Change in Industry Structure on Cournot-Nash Equilibrium", Quarterly Journal of Economics 98, (1983): 185-199.

17 Richard Posner, "The Chicago School of Antitrust Analysis", University of Pennsylvania Law Review 127, (1979), 925-948 at 939.

18 This argument assumes that the incumbent has to sell every unit of its product at the predatory price. If price discrimination is possible during the predatory pricing period, such as in the airline industry, the costs for the incumbent might be substantially lower.

19 Martin, n. 10 above at 461. 
The signalling and reputation models both consider low prices as instruments of the incumbent to mislead the (less informed) entrant into believing that market conditions are unfavourable for entry. One type of signalling models argues that a low price could (under certain conditions) be interpreted as a signal for the efficiency of the incumbent (e.g., if the entrant believes that the incumbent's low prices reflect low costs). The reputation models focus on the rationality of a price reduction in one market by means of establishing a reputation as a tough price cutter in other markets. ${ }^{20}$ This reputation might induce the entrant to retreat from entering the same or an alternative market in which the incumbent is active..$^{21}$

In a nutshell, rationality research clarifies that predation is not a universal monopolisation strategy which can be used profitably at any time by every dominant firm in every industry. Successful predation rather depends on the specifics of various market characteristics, such as entry barriers, capacity constraints, consumer behaviour, the level of product differentiation, multi-market contact, characteristics of the entrant and, last but not least, the informational situation present in the market. ${ }^{22}$ This knowledge will help to cope with stage three ('detecting predation') later on.

\section{Welfare Effects of Predation}

In the preceding section it was shown that predation can, under certain circumstances, be a profit-maximising business strategy for an incumbent facing entry. However, considering any kind of antitrust action against such a business strategy requires proof of its potential to impose overall negative welfare effects on society. The consequential question of how to measure welfare in an antitrust context is subject to ongoing discussions among antitrust scholars. ${ }^{23}$ While some researchers argue that antitrust should aim at maximising overall efficiency, others recommend concentrating on maximising consumer surplus or productive efficiency. An oftenmentioned advantage of the consumer surplus standard is that a maximisation of the consumer surplus coincides with a minimisation of the deadweight loss. However, a total welfare standard might be preferred simply because the producer surplus could be interpreted as just another form of consumer surplus. ${ }^{24}$

In the remainder of this paper, a total welfare approach is followed. With respect to the assessment of the overall welfare effects of predation, it is helpful to split up the overall welfare effect into its components (i.e., consumer surplus and producer surplus, consisting of incumbent's profits and entrant's profits) and analyse them separately in the first place. This is sketched out in Figure 2.

The consumer surplus effects of a predation strategy are depicted in Figure 2-(1). The starting point is a monopoly market in which the incumbent sets the monopoly price and the consumers realise a relatively small consumer surplus $\mathrm{CS}^{\mathrm{Mono}}$. In accordance with most (non-collusive) oligopoly models, it is reasonable to assume that the consumer surplus rises (here to $\mathrm{CS}^{\text {Duo }}$ ) if a second firm enters the market at point $t^{\text {entry }}$, because entry typically puts pressure on price and raises overall quantities. Moreover, it is consequential to assume that the consumer surplus

20 Patrick Bolton, Joseph Brodley \& Michael Riordan, "Predatory Pricing: Strategic Theory and Legal Policy", Georgetown Law Review 88, (2000): 2239-2330.

21 For an overview of empirical studies on predation, see Kai Hüschelrath, Competition Policy Analysis - An Integrated Approach, Physica, Heidelberg, 2009, 255-256.

22 For a detailed overview, see Kate \& Niels, n. 14 above.

23 For a detailed overview, see Joseph Farrell \& Michael Katz, The Economics of Welfare Standards in Antitrust, Working Paper CPC-06-061, University of California, Berkeley, 2006.

24 This is basically because consumers are shareholders of the companies who realise the profit and therefore in the longer run pocket the producer surplus as well. See Massimo Motta, Competition Policy - Theory and Practice, Cambridge University Press, Cambridge, 2004, 39-64 for a discussion. Recent theoretical research on predation and mergers has made increasing use of a consumer welfare standard. See, e.g., Cabral \& Riordan, n. 7 above and Damien Neven \& Lars-Hendrik Röller, "Consumer Surplus vs. Welfare Standard in a Political Economy Model of Merger Control”, International Journal of Industrial Organization 23, (2006): 829-848. 
during the predation period, $\mathrm{CS}^{\text {Pred }}$, is even higher than in normal duopoly competition..$^{25}$ In the post-predation period, the consumer surplus level depends on the successfulness of the predation attempt. If the entrant has to exit the market in $t^{\text {exit }}$, the consumers again only realise the small monopoly consumer surplus $\mathrm{CS}^{\mathrm{Mono}}$ until the market ends or another firm enters the market at $t^{\text {end }}$. However, if the entrant somehow survives the predation period, the consumers can enjoy the higher consumer surplus $\mathrm{CS}^{\text {Duo }}$ for the rest of the post-predation period. Therefore, from an isolated consumer welfare perspective, it is essential to keep the entrant in the market to realise the higher consumer welfare under competition. In fact, consumer welfare when predation takes place (but is unsuccessful) is higher than when the incumbent accommodates the entrant.

The entrant's profits are another welfare component which has to be considered in a total welfare analysis. As Figure 2-(2) shows, the entrant makes zero profits in the pre-predation period and realises even negative profits during the predation period. If the entrant manages to survive the predation period, it realises a duopoly profit until the market ends or another firm enters the market. Therefore, from the isolated viewpoint of the entrant, it is profit-maximising for him to be accommodated. If the incumbent decides to predate, the entrant's profits in the post-predation period have at least to outweigh the losses incurred in the predation period to make entry profitable for the entrant.

The incumbent's profits (Figure 2-(3)) are at the high monopoly level in the pre-predation period and drop, because of the predation strategy, to a negative level in the predation period after the entrant has entered the market. As already shown, the profits of the incumbent are assumed highest if it imposes a successful predation strategy (which forces the entrant to leave the market in $t^{\text {exit }}$ ), as it can then regain its monopoly profits. However, if the entrant survives the predation period, the profits of the incumbent are reduced to a duopoly level and the incumbent consequently loses its excess profits. The predation investment of the incumbent - given by the differential between the duopoly profits and the predation profits in the predation period - turns out to be unprofitable.

The overall welfare effect of a predation strategy can be derived by adding up the three welfare components just analysed. If the predation attempt of the incumbent is successful, it is straightforward to show that the net overall welfare would still increase - compared to a continuation of the monopoly situation - as long as (see Section 9.1 for the proof)

$$
\mathrm{CS}^{\text {Pred }}-\mathrm{CS}^{\text {Mono }}>\pi_{\mathrm{I}}^{\text {Mono }}-\left(\pi_{\mathrm{E}}^{\text {Pred }}+\pi_{\mathrm{I}}^{\text {Pred }}\right) \text {. }
$$

Inequality (1) basically says that the consumer surplus gain in the predation period has to be larger than the loss in producer surplus in the same period to increase overall welfare. As predation is assumed to be successful, the market performance in the post-predation period is the same as in the 'continuous monopoly' counterfactual scenario and therefore of no relevance for calculating the net welfare effect.

In an alternative scenario, it is assumed that predation is unsuccessful for the incumbent because the entrant somehow - e.g., with the help of the antitrust authority - survives the predation period. Comparing such a situation with the realised welfare in the scenario of successful predation, it is again straightforward to show that the net welfare increases as long as (see Section 9.2 for the proof)

$$
\mathrm{CS}^{\text {Duo }}-\mathrm{CS}^{\text {Mono }}>\pi_{\mathrm{I}}^{\text {Mono }}-\left(\pi_{\mathrm{E}}^{\text {Duo }}+\pi_{\mathrm{I}}^{\text {Duo }}\right) .
$$

Inequality (2) says that the consumer surplus gain due to increased competition (in the postpredation period) must be larger than the loss in producer surplus due to competition (in the postpredation period) in order to realise a net increase in overall welfare. Due to the deadweight loss caused by monopoly prices, this condition typically holds, and the welfare gain increases with the spread between the pre-predation price level and the price level which would exist under

25 Sufficient capacities, which allow the saturation of the risen demand, and the absence of price discrimination are assumed. 
perfect competition. However, there are situations - such as the so-called natural monopoly - in which the derived inequality would not hold.

Summing up the section on the welfare effects of predation, it can be said that making predation unsuccessful by introducing suitable antitrust rules and interventions has the potential to increase overall welfare. This is especially true if it is considered that successful predation in one market may cause spillovers to other markets in the sense that it deters entry into other markets in which the incumbent operates, causing additional welfare losses. It is therefore worthwhile to continue thinking about the design and especially the implementation of rules against predation. 
Fig. 2. Isolating the welfare effects of predation

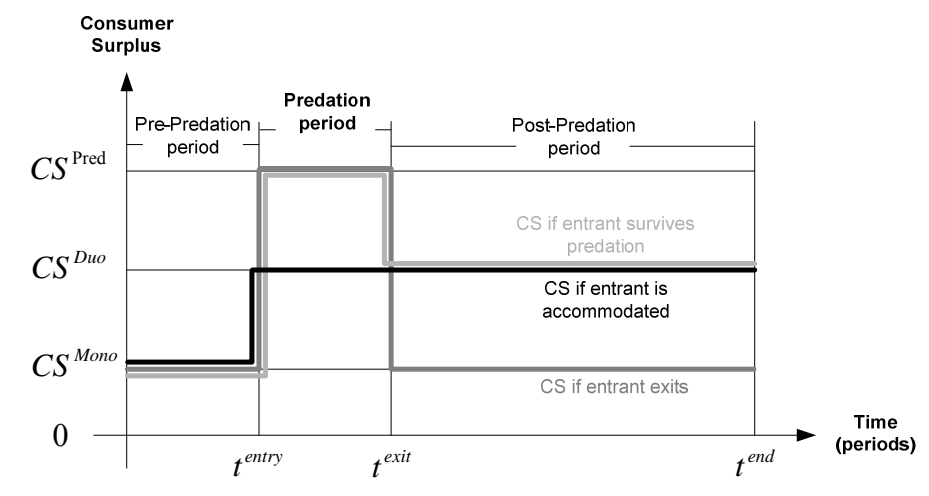

(1) Consumer surplus effects

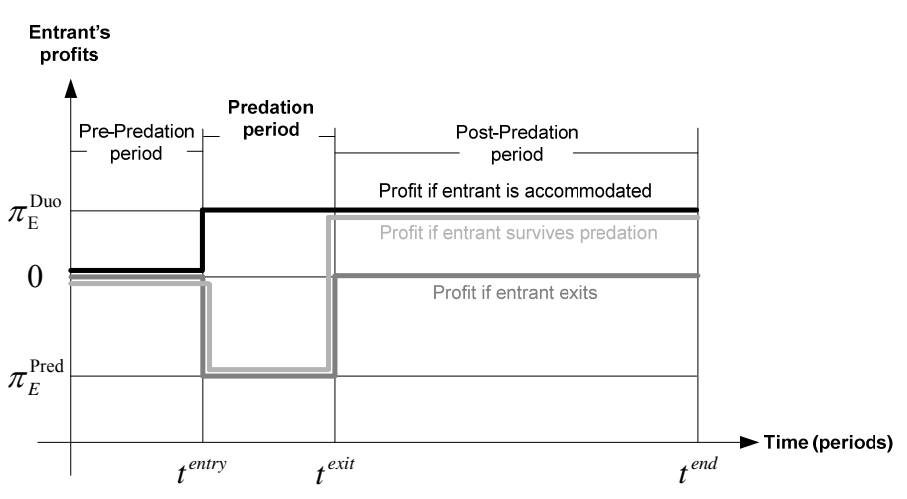

(2) Entrant's profit effects

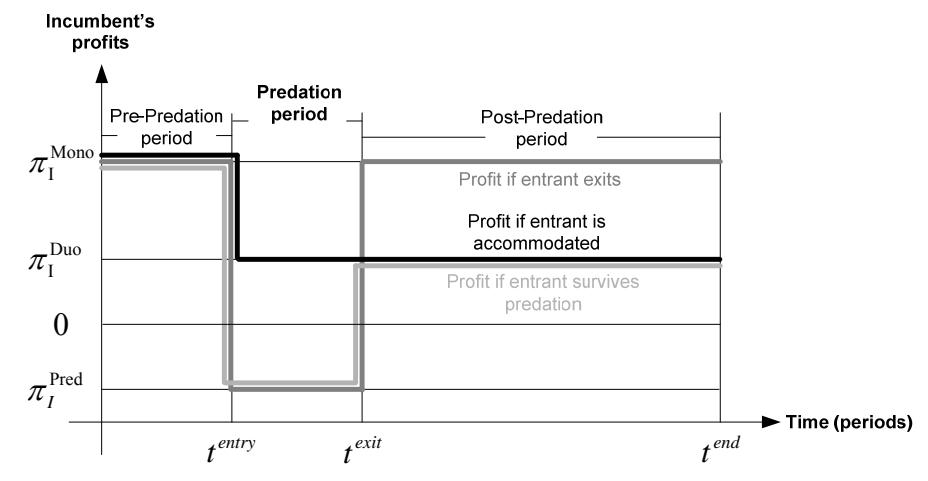

(3) Incumbent's profit effects 


\section{Detecting Predation}

The key finding thus far is that predation can be a rational business strategy with negative implications on overall welfare. In order to use this knowledge for antitrust purposes, the question of how to detect predation in real antitrust cases becomes crucial. In general, antitrust law offers two different answers: per se rules and the rule of reason. The per-se-rule approach prohibits a certain behaviour generally. Accordingly, the antitrust authority only has to answer the question 'Did the incumbent engaged in the proscribed practice?' If the answer is Yes, the antitrust authority and afterwards the courts are committed to suppress the behaviour and eventually fine the respective firm, independent of the question whether competition has been an injured or not. ${ }^{26}$ The per se commitment to suppression and punishment aims at creating a deterrence effect for firms who consider the adoption of such prohibited strategies. The central characteristics of the per se rule predestine the approach for types of behaviour that are clearly identifiable (for firms as well as for the antitrust authority) and have clear (and almost certain) negative welfare consequences. If these preconditions are not met, some kind of rule of reason approach is applicable. The rule of reason accommodates the more frequent case that the efficiency-enhancing effects of a certain behaviour have to be compared with the anticompetitive effects.

In addition to the choice between two types of control strategies, the antitrust authority further has the choice of when to use a certain control strategy, namely before an infringement actually takes place (ex ante) or after a certain infringement occurred (ex post). This choice of the timing of control together with the different control strategies lead to the detection options presented in Table 1.

Table 1. Detection options

\begin{tabular}{|c|c|c|c|c|}
\hline & & \multicolumn{3}{|c|}{ Control strategy } \\
\hline & & per se & rule of reason & No rule \\
\hline $\begin{array}{l}\overline{0} \\
\vdots \\
\vdots \\
0 \\
4\end{array}$ & $\begin{array}{c}\text { ex } \\
\text { ante }\end{array}$ & I & II & n.a. \\
\hline$\underset{\underbrace{}}{\stackrel{\Xi}{\mathbb{E}}}$ & $\begin{array}{c}\text { ex } \\
\text { post }\end{array}$ & III & IV & n.a. \\
\hline
\end{tabular}

At first glance, it might be surprising to consider ex ante control (options I and II) as antitrust options, because the timing of control criterion is frequently used to separate regulation (ex ante) from antitrust interventions (ex post). However, the case of merger control has shown that ex ante actions might be a sensible antitrust option as well, partly because such a kind of invention could reduce the firms' uncertainty about the legality of its merger plans before they are implemented. ${ }^{27}$

Turning from general detection options to detecting predation, it is pivotal for an antitrust authority to find out if the prices of an incumbent are unreasonably low, aiming at swamping the entrant out of the market. Consequently, the usage of an (ex post) per se rule (as an objective

26 See Terry Calvani, “Some Thoughts on the Rule of Reason”, European Competition Law Review 22, (2001): 201-207.

27 On the other hand, the performance of an ex ante approach heavily depends on a good information situation and good analysing capabilities within the antitrust authority (as it has to assess the likely competitive effects of a merger in the future). 
indicator) seems to be the obvious antitrust reaction. Consistently, in 1975, Areeda and Turner ${ }^{28}$ proposed a pure cost-based rule to define and detect predatory pricing in antitrust cases. Under this approach, a price at or above the defendant's average variable cost (applied as a surrogate for short-run marginal cost) is conclusively deemed lawful and a price below the defendant's average variable cost is conclusively deemed unlawful, as a profit-maximising firm would never charge such a price. ${ }^{29}$

As every rule of thumb, the Areeda-Turner rule has certain drawbacks. ${ }^{30}$ The rule is, for instance, static and consequently ignores the strategic intertemporal nature of every predation strategy. Furthermore, economic research has shown that the Areeda-Turner rule is quite imprecise insofar as pricing below average variable cost can be welfare-enhancing and pricing above average variable cost can be predatory (following the game-theoretic characterisation of predation derived in section 2.). ${ }^{31}$ In other words, there is no clear link between the AreedaTurner standard and total welfare which would be desirable for the efficient translation into an antitrust enforcement rule. ${ }^{32}$ Even one initially praised advantage of the rule, its manageability, disappeared as it turned out that the rule is rather difficult to apply in court (as cost data delivered by firms normally does not collude perfectly with the economic cost concepts.

Since the deflagration of the initial Areeda-Turner enthusiasm, antitrust law and economics research has focused on especially three major areas. First, considerable effort has been undertaken to develop superior rules which try to avoid several problems of the Areeda-Turner rule. ${ }^{33}$ Williamson ${ }^{34}$, for instance, invented an (ex ante) 'no post-entry output increase' rule in 1977, followed by Baumol's (ex ante) 'no post-exit price increase' rule two years later. ${ }^{35}$

Second, more appropriate cost concepts for predation cases have been developed. The most influential proposals of this strand of research are the concept of average avoidable cost by Baumol $^{36}$ and the average incremental cost standard defined by Bolton, Brodley and Riordan ${ }^{37}$, which both address the problem in practical predation cases to distinguish between the various

28 Phillip Areeda \& Donald Turner, "Predatory Pricing and Related Practices under Section 2 of the Sherman Act", Harvard Law Review 88, (1975): 697-733.

29 It is important to add that the rule is "designed around the notion that predatory pricing is rare and that any policy on predation should minimise deterrence to competitive pricing". Terry Calvani \& James Lynch, "Predatory Pricing under the Robinson-Patman and the Sherman Acts: An Introduction", Antitrust Law Journal 51, (1982): 375-400 at 381.

30 See, e.g., Simon Bishop and Mike Walker, The Economics of EC Competition Law: Concepts, Application and Measurement, Sweet \& Maxwell, London, 2002, at 231.

31 See especially Geoff Edwards, "The Perennial Problem of Predatory Pricing”, Australian Business Law Review 30, (2002): 170-201 and Aaron Edlin, "Stopping Above-Cost Predatory Pricing", Yale Law Journal 111, (2002): 941-991.

32 See Louis Kaplow \& Carl Shapiro, Antitrust, Working Paper, Harvard University, Cambridge, 2007 , at 117.

33 See Joseph Brodley \& George Hay, "Predatory Pricing. Competing Economic Theories and the Evolution of Legal Standards", Cornell Law Review 66, (1981): 738-803.

34 See Oliver Williamson, "Predation: A Strategic and Welfare Analysis", Yale Law Journal 87, (1977): $284-340$.

35 See William Baumol, "Quasi-Permanence of Price Reductions: A Policy for Prevention of Predatory Pricing”, Yale Law Journal 89, (1979): 1-26.

36 See William Baumol, "Predation and the Logic of the Average Variable Cost Test", Journal of Law and Economics 39, (1996): 49-72.

37 See Bolton, Brodley \& Riordan, n. 20 above. 
cost test in a multi-product firm context. ${ }^{38}$ To give an example of these cost concepts, suppose that the cost function $C\left(Q_{1}, Q_{2}\right)$ for the two products 1 and 2 is given as follows: ${ }^{39}$

$$
C\left(Q_{1}, Q_{2}\right)=F_{c}+F_{1}+S_{1}+F_{2}+S_{2}+V\left(Q_{1}\right)+W\left(Q_{2}\right)
$$

where $\left(F_{c}\right)$ representing common fixed cost (including sunk), $\left(F_{1}, F_{2}\right)$ being fixed non-sunk costs attributable to only one good, $\left(S_{1}, S_{2}\right)$ representing fixed sunk (before predation) costs attributable to only one good, $\left(V\left(Q_{1}\right), W\left(Q_{2}\right)\right)$ being variable costs and $\left(Q_{1}, Q_{2}\right)$ representing the sold quantities. Given these definitions, the respective cost standards for product 1 are defined as follows:

- Marginal cost $=V^{\prime}\left(Q_{1}\right)$

- Average variable cost $=V\left(Q_{1}\right) / Q_{1}$

- Average total costs $=$ unknown due to common costs

- Average incremental cost $(\mathrm{AIC})=\left[F_{1}+S_{1}+V\left(Q_{1}\right)\right] / Q_{1}$

- Average avoidable cost $(\mathrm{AAC})=\left[F_{1}+V\left(Q_{1}\right)\right] / Q_{1}$

Given these definitions, Bolton et al. ${ }^{40}$ propose that a price below $A A C$ should be considered unlawful and a price above $A I C$ should be considered lawful. A price between $A I C$ and $A A C$ would lie in a grey area, perhaps presumptively lawful.

Third, an (ex post) two-step standard for predation strategies was developed as an amendment to the compulsory price-cost comparisons. The basic idea is that before time-consuming cost calculations are undertaken, the general probabilities of future supra-competitive pricing and recovery of losses by the predator should be considered first to get a rough estimate whether predation could generally be a problem in the market at hand. This proposal was basically motivated by a decision-theoretic framework proposed by Joskow and Klevorick ${ }^{41}$, in which the authors favour a policy "that would minimise the sum of the expected costs of error and the costs of implementation". The cost of error can be classified, as in statistical terminology, as type I and type II errors. A type I error would be an erroneous condemnation of procompetitive behaviour, while the failure to condemn an instance of anticompetitive behaviour would be a type II error.

Recent research has focused mainly on the extension of the two-step standard to a complete (ex post) rule-of-reason approach, which especially tries to integrate the fundamental gametheoretic insights as well as the new cost concepts sketched above. ${ }^{42}$ Current research competition between different frameworks is tough ${ }^{43}$ and becomes increasingly differentiated, as

38 (Short-run) average avoidable costs are the average per unit cost that the predator would have avoided during the period of below-cost pricing had it not produced the predatory increment of sales. (Long-run) average incremental costs are the per unit cost of producing the added output to serve the predatory sales. See, e.g., Motta, n. 24 above at 447-448 and Andreas Lutz, Misidentified Incremental Costs and Irrational Results, NERA Antitrust Insights, Issue September/October, Los Angeles, 2004.

39 Thomas Ross, "Sunk Costs and the Entry Decision", Journal of Industry, Competition and Trade 4, (2004): 7993.

40 See Bolton, Brodley \& Riordan, n. 20 above.

41 Paul Joskow \& Alvin Klevorick, “A Framework for Analyzing Predatory Pricing Policy”, Yale Law Journal 89, (1979): 213-270 at 218.

42 Generally, the development of such frameworks can be interpreted as attempts by post-Chicago economists to increase the significance of their work or models in court decisions. Up to date, the courts have been reluctant to make use of most of these ideas (at least with respect to predation) because of, for example, low robustness, measurement difficulties or simply a low manageability. See generally Herbert Hovenkamp, "Post-Chicago Antitrust: A Review and Critique", Columbia Business Law Review 2001 (2): 257-337 and Kenneth Elzinga \& David Mills, "Predatory Pricing and Strategic Theory" Georgetown Law Journal 89, (2001): 2475-2494

43 See, e.g., Bolton, Brodley \& Riordan, n. 20 above and Emmanuel Mastromanolis, "Predatory Pricing Strategies in the European Union: A Case for Legal Reform", European Competition Law Review 19, (1998): 211-224. 
special industries and special industry characteristics such as network effects become the focal point of interest. ${ }^{44}$

Probably the most influential general attempt to construct a full rule-of-reason approach is the four stages framework of Bolton et al..$^{45}$ The authors recommend starting case work with an examination of the general market conditions in order to sort out unlikely predation cases, such as those in which the defendant does not have market power, no significant entry barriers are present or the respective entrant is strong. The second stage looks for a general scheme of predation and supporting empirical evidence, followed by an assessment of the probability of recoupment in stage three. Subsequently, in stage four, prices and costs are examined, taking the 'average incremental cost' standard into account. The framework is amended by a so-called efficiency defense, which aims at "eliminating cases where below-cost pricing by a firm with market power is likely to be welfare-enhancing, rather than predatory. In these cases, the sacrifice of present profits through low pricing is justified for reasons other than exclusion or disciplining of rivals". ${ }^{46}$ Those reasons include two-sided markets, product promotions, penetration pricing in network industries, learning by doing, pricing in systems markets, monopoly with complementary products, irreversible exit, industry rationalisation, encouraging additional infra-marginal sales and disposal of excess or obsolete stock. ${ }^{47}$

\section{Intervening Against Predation}

'Detecting' is a necessary but not sufficient condition for 'enforcing'. Even the cleverest detection rule remains an academic mind game if it is not applied in the sense that possible infringements are not pursued and possibly punished. Thoughtful answers to this intervention question are essential, as generally "[t]oo little enforcement leads to bad behavior and monopoly power, whereas too vigorous enforcement may deter firms from pursuing desirable forms of competition for fear that this competition will be misinterpreted". ${ }_{48}$

To ensure respect for legal prohibitions, the law and economics literature works out three general methods: ${ }^{49}$ prevention, stimulating moral commitment and altering the balance of expected cost/gain of violations. The preceding section already revealed the two basic control strategies an antitrust authority can choose from to detect misconduct: a per se rule or a rule-ofreason analysis. The choice of when to use a certain control strategy, namely before an infringement actually takes place (ex ante), after a certain infringement occurred (ex post) or simply not to intervene at all (no control) leads to the five detection options shown in Table 1 in the preceding section.

Besides the choice of the control strategy and the timing of control, the antitrust authority has another decision variable: the type of intervention. In general, three types of interventions are available for an antitrust authority: fines, behavioural remedies and structural remedies. A fine is commonly understood as imprisonment or an amount of money which must be paid for a proved misdemeanour or felony; a remedy comprises all other possible non-pecuniary interventions with either a behavioural or a structural focus. Conceptually, fines and remedies differ considerably,

44 See, e.g., Adriaan Ten Kate \& Gunnar Niels (2004), Below Cost Pricing in the Presence of Network Externalities, in: Swedish Competition Authority (Ed.), The Pros and Cons of Low Prices, Elanders Graphic Systems, Göteborg, 2004, 97-127 and Clinton Oster \& John Strong (2001), Predatory Practices in the U.S. Airline Industry, Working Paper, Indiana University, Bloomington, 2001.

45 Bolton, Brodley and Riordan, n. 20 above at 2262.

46 Ibid., 2274.

47 See Edwards, n. 31 above.

48 See Dennis Carlton \& Jeffrey Perloff, Modern Industrial Organization, Harper Collins, New York, 2000 , at 361.

49 See generally Wouter Wils, The Optimal Enforcement of EC Antitrust Law, Kluwer, The Hague, $2002,8$. 
as "[r]emedies cure, correct, or prevent unlawful conduct, whereas sanctions penalise or punish it". ${ }^{50}$

Table 2 below shows the resulting intervention options determined by the type of intervention and the timing of control. Ex ante interventions in case of predation are only considered in combination with behavioural remedies, simply because the typical law system hardly allows other interventions for prevention purposes. Ex post, all three intervention options are possible and have actually been used in the history of predatory enforcement.

Table 2. Intervention options

\begin{tabular}{|c|c|c|c|c|}
\hline & & \multicolumn{3}{|c|}{ Type of intervention } \\
\hline & & Fine $(€)$ & $\begin{array}{c}\text { Behavioural } \\
\text { remedies }\end{array}$ & $\begin{array}{c}\text { Structural } \\
\text { remedies }\end{array}$ \\
\hline $\begin{array}{l}\overline{0} \\
\vdots \\
\vdots \\
0 \\
\overleftarrow{0}\end{array}$ & ex ante & n.a. & A & n.a. \\
\hline : & ex post & B & $\mathrm{C}$ & $\mathrm{D}$ \\
\hline
\end{tabular}

Merging Table 1 (Detection) and Table 2 (Intervention) leaves in theory 17 enforcement combinations. ${ }^{51}$ For the remainder of the paper, only the following combinations are considered further: no rule, ex ante per se rule with behavioural remedy, and ex post rule of reason with fine and/or behavioural remedies. Figure 3 sketches the consumer surplus implications over time for these enforcement options.

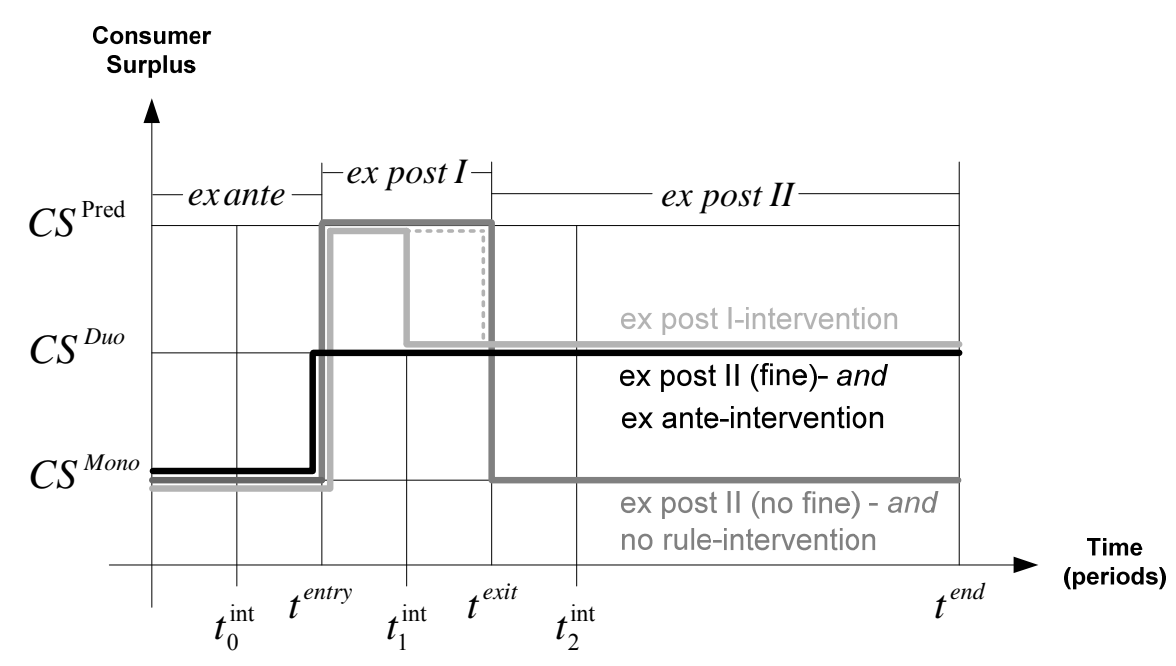

Fig. 3. Consumer surplus effects of different enforcement options

The basic assumptions underlying Figure 3 were already explained in section 2 (see Figure 1). In addition, Figure 3 defines three new points in time: $t_{0}^{\text {int }}$ is assumed to be the point at which the antitrust authority commits itself to a certain ex ante rule; $t_{1}^{\text {int }}$ is assumed to be the point at which

50 Organisation for Economic Co-operation and Development, Remedies and Sanctions in Abuse of Dominance Cases, Paris, 2007, 7.

51 No rule plus the 16 possible combinations of I, II, III and IV from Table 1 and A, B, C and D from Table 2. 
the antitrust authority is able to end the predation attempt before the entrant has to leave the market (ex post I enforcement) ${ }^{52}$; and $t_{2}^{\text {int }}$ is assumed to be the point at which the antitrust authority is able to prove predation after the entrant has left the market (ex post II enforcement). This basic set-up allows the following detailed characterisation of the selected three predation enforcement options no rule, ex post rule of reason and ex ante per se rule.

\subsection{No rule}

In a no-rule approach, the antitrust authority on principle does not encroach upon any event of unreasonably low prices. Consequently, the incumbent is able to implement its predation strategy and swamps out the rival at point $t^{\text {exit }}$ (see Figure 3 above). The consumers can enjoy the additional high consumer surplus during the predation period but are condemned, after the forced exit of the rival, to the high monopoly price and the correspondingly low consumer surplus until the market ends or another firm enters the market at point $t^{\text {end }}$. In terms of overall welfare, Section 4 above has already shown that a no-rule approach is inferior to an (ex post) antitrust intervention as long as the gain in consumer surplus due to increased competition is larger than the loss in producer surplus due to competition.

Despite the clear result that a no rule approach is typically not the welfare-maximizing policy reaction to predation strategies, a considerable number of antitrust lawyers and economists believe that the best predation enforcement is no enforcement (e.g., Bork or McGee). One frequently used argument by supporters of the Chicago school is that any antitrust action against predation is unnecessary, because the market forces (in the long run) will automatically select the most efficient firms and lead to efficient market outcomes. Another argument says, as sketched above, that predation is irrational generally and that suspicious cases only represent the richness of normal competitive behaviour. Both lines of arguments inevitably lead to the same conclusion: the no-rule approach is the first and only sensible enforcement option as a matter of principle.

Even if the welfare-reducing potential of predation in some cases is acknowledged, some scholars believe that it is hardly possible for an antitrust authority to distinguish normal competitive behaviour from harmful predatory behaviour. Generally speaking, dynamic market behaviour is assumed to be too complex to be interpreted correctly by the antitrust authority..$^{53}$ Interventions therefore contain a high danger of errors ${ }^{54}$ and consequently socially harmful antitrust interventions. ${ }^{55}$ A closely related argument says that predation should not be on the antitrust enforcement agenda because it is "rarely tried, and even more rarely successful". ${ }^{66}$ In both cases, the no-rule approach is the first choice following an implicit cost-benefit assessment.

The universal correctness of such a cost-benefit assessment can certainly be questioned. Although it is of course sensible to choose the optimal level of antitrust enforcement subject to

52 For the rest of the paper, it is assumed that $t_{1}^{\text {int }}=t_{\text {exit }}$. In other words, the entrant is rescued just before he would have to exit the market.

53 See Joskow \& Klevorick, n. 41 above at 217.

54 Generally, an immediate consequence of an imperfect world is that the antitrust authority is in danger of making welfare-reducing case decisions by (a) detecting and punishing an attempt of predation which was in fact procompetitive behaviour (type I error, 'punishing the innocent'), (b) not detecting and punishing instances of predation (type II error, 'acquitting the guilty') and (c) correctly detecting predation but choosing suboptimal remedies which harm overall welfare (type III error, 'suboptimal punishment of the guilty'). Furthermore, (d) general enforcement costs, as well as (e) costs from firms using alternative strategies to achieve the same ends and (f) costs due to non-predatory firms acting to avoid being mistaken for predators, must also be taken into account. See David Easley, Robert Masson \& Robert Reynolds, "Preying for Time", Journal of Industrial Economics 33, (1985): 445-460.

55 In this respect, it should be mentioned that antitrust rules (e.g., against predation) might demotivate incumbents to undertake welfare-enhancing activities (e.g., to drop prices) just because they are afraid of being (wrongly) charged by the antitrust authority and the court(s).

56 Matsushita Elec. Indus. Co. v. Zenith Radio Corp., 475 US at 589 (1986). 
cost-benefit considerations ${ }^{57}$, it is unclear whether this generally leads to a no-rule approach as the first choice. As shown by Easterbrook ${ }^{58}$, the society's welfare is maximised when the legal rule holds to a minimum the sum of, first, the welfare loss from the infringement; second, the welfare loss from an erroneous condemnation of procompetitive behaviour; and third the costs of administering the legal rule. For the following reasons, the supporters of a no-rule approach might underestimate the benefits and overestimate the costs of other forms of predation enforcement.

First, a no rule approach is equal to a minimisation of type I errors while maximising type II errors. However, it is quite unlikely that both types of errors occur in the same frequency and gravity in every type of antitrust case. For example, in a monopoly market the likelihood of a type I error is typically considerably smaller than in an oligopoly market. However, consumers typically gain relatively more from introducing competition in a monopoly market; hence, a type II error is likely to be big. Consequently, it might be sensible to think about using different enforcement standards/options for predation in monopoly markets and in oligopoly markets.

Second, the frequently used argument that predation is 'rarely tried, and even more rarely successful' is flawed from the perspective of recent theoretical and empirical work on predation. Even if predation is not frequently observed, such a finding might state little about the importance and influence of a predation strategy on industry competition, because it neglects the important reputation effects which aim at spilling over to other entrants in the same or adjacent markets. In other words, predation would be an expensive (and probably irrational) strategy, if an incumbent would have to apply it frequently after market entry occurred. Part of the value of a predation strategy stems from its pre-entry deterrence effect, created by a combination of uncertainty and reputation in the head of the entrant. The incumbent reduces the profit expectations of the potential entrant, leading - as the case may be - to its decision not to enter at all. Consequently, observable cases of predation should be relatively seldom and could be interpreted as investments of the incumbent in the credibility of its strategic signals. Therefore, a no-rule approach cannot be justified by simply demonstrating that a certain strategic option is rarely observable in a certain industry. ${ }^{59}$

In short, although cost-benefit calculations might under many circumstances justify a no-rule approach, it is doubtable that such an approach is generally the optimal predation enforcement option.

\subsection{Ex post rule of reason}

Generally, an ex post predation enforcement can be separated into an ex post I approach in which the antitrust authority intervenes before the entrant has to exit the market (point $t_{1}^{\text {int }}$ in Figure 3) and an ex post II approach in which the authority intervenes after the entrant has left the market (point $t_{2}^{\text {int }}$ in Figure 3). In an ex post I approach, the antitrust authority has to answer two fundamental questions. The first refers to competition in the post-predation period. In that

57 This is a basic result of many 'optimal enforcement' models. For instance, Souam shows that it is welfareoptimal to tolerate some degree of collusion in the market when interventions are costly. See Said Souam, “Optimal Antitrust Policy under Different Regimes of Fines", International Journal of Industrial Organization 19, (2001): 1-26.

58 See Frank Easterbrook, “The Limits of Antitrust”, Texas Law Review 63, (1984): 1-40.

59 Additionally, the consensus among some commentators that 'predatory pricing schemes are rarely tried, and even more rarely successful' might have become a self-fulfilling prophecy, because multiple barriers faced by predatory pricing plaintiffs make it almost impossible to get past summary judgment. See Richard Zerbe \& Donald Cooper, An Empirical and Theoretical Comparison of Alternative Predation Rules, Texas Law Review 61, (1982): 655-715. Hemphill explains that because of the difficulty of winning a predation case in the United States, the government avoids an explicit predatory pricing allegation and instead tries to reach related conduct under the general sections standard. Consequently, it might be highly misleading to conclude from the few predation cases in the US that the whole form of anticompetitive behaviour is irrelevant. It might only be deterred by the high standards of proof and substituted by other forms of anticompetitive behaviour. See Hemphill, n. 11 above at 585. 
respect, the antitrust authority has to decide on a minimum price for the incumbent which terminates the infringement and 'restores' competition. The second question to be assessed refers to the fixing of an ex post fine for the infringement. In terms of overall welfare, section 4 has already shown that an ex post I approach is superior to a no-rule approach as long as the following condition holds:

$$
\mathrm{CS}^{\text {Duo }}-\mathrm{CS}^{\mathrm{Mono}}>\pi_{\mathrm{I}}^{\text {Mono }}-\left(\pi_{\mathrm{E}}^{\text {Duo }}+\pi_{\mathrm{I}}^{\text {Duo }}\right) .
$$

In an ex post II approach, the entrant has already left the market and a decision about the termination of the infringement is obsolete. Consequently, the antitrust authority only has to answer the question of how to fine the incumbent. Both approaches will be discussed in the following paragraphs.

\section{Ex post I approach - Terminating the infringement}

After detecting predation, the antitrust authority has to terminate the infringement. How this should be done largely depends on how predation was detected in the first place. If the antitrust authority undertook price-cost comparisons, it has a picture of the costs of the incumbent and can therefore estimate a minimum price for the incumbent which covers (the used measure of) its costs. It is important to note that such a price must not ensure that the entrant can reach the break-even point. The aim is solely to secure that the incumbent does not price unfairly low ${ }^{60}$; it is a measure to secure (possible) competition, not competitors.

If the antitrust authority derived the non-cooperative Cournot-Nash equilibrium as a benchmark for procompetitive behaviour and proved predatory conduct by showing that actual market prices were lower, it has all necessary information to fix the correct minimum price for the incumbent. In that case, however, the efficiency of the entrant plays a role in the investigation, as it has to be shown first that the entrant 'is efficient enough' (and the market large enough) to reach break-even in a non-cooperative Cournot equilibrium (and only the incumbent's pricing policy turns this entry value negative).

Independent of the exact way of deriving the minimum price for the incumbent, the antitrust authority is in danger of choosing an improper mode of interference against (correctly identified) predatory behaviour. Such an error was introduced as a type III error. ${ }^{61}$ If the minimum price is too low (and therefore still predatory), the entrant might still make losses and may have to exit the market (at a later point in time). If the minimum price is too high, the incumbent suffers too much, which also distorts competition and especially reduces the incumbent's innovation and investment incentives and probably (through the creation of credible signals) in the economy as a whole.

Comparable problems are created with respect to the length of the period for which the minimum price for the incumbent should be valid. From a theoretical point of view, it is unclear why a minimum price should be subject to a time limit at all, as it just corrects misbehaviour that does not turn into approved misbehaviour after a certain amount of time. However, practical reasons such as the constant monitoring efforts of (probably asymmetric) cost and demand shocks in the industry (and the corresponding adjustments of the minimum price) make it economically sensible to constrain the minimum price to a certain time period. Such a time limit also reflects the belief that the entrant becomes established in the market after some time and probably is not that vulnerable to predation attacks any more.

60 There has recently been an interchange of ideas on the question of the relevance of above-cost predation by Edlin and Elhauge. This discussion is not considered further in this paper. See Edlin, n. 31 above and Einar Elhauge, Why Above-Cost Price Cuts to Drive Out Entrants Are Not Predatory: And the Implications for Defining Costs and Market Power, Yale Law Journal 112, (2003): 681-827.

61 Michal Gal, "Harmful Remedies: Optimal Reformation of Anticompetitive Contracts", Cardozo Law Review 22, (2000): 91-132 at 93 . 


\section{Ex post I approach - Determination of fines}

If the antitrust authority ends the predation attempt before the entrant has left the market, the fixing of fines is somewhat difficult. This is because the intervention of the antitrust authority makes the incumbent's investment unprofitable before it has a chance to earn a positive return on investment. In other words, the gain for the incumbent is negative at that point. Additionally, there is no harm to the consumers, as they enjoy a higher consumer surplus than in the duopoly counterfactual during the predation period. Total welfare is only reduced if the entrant has a large efficiency advantage and the incumbent has to accept large losses to drive down the entrant's profits to zero. Consequently, the only party which is harmed by the interrupted predation strategy is the entrant, as the predation attempt took away the duopoly profit he would have realised in the competitive situation. Consequently, the fixing of this amount can be derived easily in theory by multiplying the number of predation periods with the difference between duopoly profits and predation profits. Additionally, total welfare is further reduced by the enforcement costs invested by the antitrust authority. The consequential conclusion of this line of thinking is that the incumbent does not have to pay a fine in an ex post I approach, as he already fined himself by selling products at a suboptimal low price during the predation period. However, he should bear the enforcement costs.

\section{Ex post II approach - Determination of fines}

In an ex post II approach, the authority ends the predation attempt after the entrant has exited the market. In other words, predation was successful for the incumbent in the sense that it regained its monopoly position. Consequently, the antitrust authority only has to answer the question of how to fine the incumbent.

Generally, the antitrust authority has the choice between gain-based and harm-based fines. The economically appropriate way to fix the level of such a fine is the subject of ongoing discussions among antitrust scholars. Simply the aim of setting antitrust fines is one hotbed of dispute. While some scholars see fines as an important instrument in the prevention of violations (i.e., the creation of a deterrence effect), others understand fines more as reparation of the harm caused by the misdemeanour or felony. ${ }^{62}$ Although both concepts do not necessarily fall foul with each other, both concepts can lead to quite different fine levels.

With respect to the ex post II approach in predation enforcement, a deterrence effect would not be reached as long as the fine simply reduces but not matches the expected (net) excess profits of the incumbent (ex post II (no fine) approach). However, if the antitrust authority can credibly commit ex ante to imposing a fine which takes away that (net) excess profit of (see Section 9.3 for the proof)

$$
\mathrm{F}_{\text {Gain based }}=\beta\left(\pi_{\mathrm{I}}^{\text {Mono }}-\pi_{\mathrm{I}}^{\text {Duo }}\right)+\alpha\left(\pi_{\mathrm{I}}^{\text {Pred }}-\pi_{\mathrm{I}}^{\text {Duo }}\right)
$$

such an approach would realise the same overall consumer surplus as the ex ante approach sketched below. This is simply because the incumbent would anticipate before applying the predation strategy that it will get caught and that the fine would take away the excess profit.

Although such a gain-based fine looks justified and attractive in the first place, theoretical research in law and economics has shown that so-called harm-based 'optimal' fines have under fairly general assumptions certain advantages over gain-based fines. ${ }^{63} \mathrm{In}$ situations, for instance, in which certain forms of behaviour harm the society less than it brings the offender, the offender would still commit the offence (and pay the fine). In such an environment, gain-based fines would lead to over-deterrence, as they would prevent such 'efficient' offences. ${ }^{64}$ Additionally,

62 See Wils, n. 49 above at 10.

63 Ibid., 22.

64 This argument is based on the general work of Becker, who shows that even if the enforcement costs are zero, it is not economically justified to deter all violations, as some offences are efficient in the sense that the gain to the offender exceeds the harm to the victim. See Gary Becker, "Crime and Punishment: An Economic Approach", Journal of Political Economy 76, (1968): 169-217. 
gain-based fines might also lead to a problem of under-deterrence, which is caused when errors in the estimation of harm/gain occur. Underestimating the gain would lead to a complete loss of the deterrence effect as the offender would still make a profit while underestimating the harm could still hold up the deterrence effect (as the fine might still be higher than the gain).

Although harm-based fines might indeed have certain advantages over gain-based fines, it is not straightforward how harm should be defined. A frequently used definition for deterring antitrust violations was derived by Landes ${ }^{65}$ based on the general work of Becker. ${ }^{66}$ Landes shows that the "optimal penalty should equal the net harm to persons other than the offender" ${ }^{67}$ In the context of predation and referring to the set-up of Figure 3, the optimal harm-based fine is given by the following expression (see Section 9.3 for the proof): 68

$$
\mathrm{F}_{\text {Harm based }}=\alpha\left[\left(\mathrm{CS}^{\text {Duo }}-\mathrm{CS}^{\text {Pr ed }}\right)+\left(\pi_{\mathrm{E}}^{\text {Duo }}-\pi_{\mathrm{E}}^{\text {Pred }}\right)\right]+\beta\left[\left(\mathrm{CS}^{\text {Duo }}-\mathrm{CS}^{\text {Mono }}\right)+\pi_{\mathrm{E}}^{\text {Duo }}\right] .
$$

In the predation period $\alpha$, net harm to others is given by the sum of the difference between the duopoly and predation consumer surplus (harm to consumers) and the difference between the entrant's duopoly and predation profits (harm to other producers). If predation is successful, the net harm to others in the post-predation period $\beta$ is given by the difference between the duopoly and the monopoly consumer surplus and the entrant's duopoly profits it would have earned without a successful predation strategy. The overall net harm to others shown above is just the sum of the two expressions.

\section{Ex post I versus ex post II approach}

The analysis so far differentiated between an ex post I approach in which the antitrust authority intervenes before the entrant has to leave the market and an ex post II approach in which the antitrust authority intervenes after the entrant exited the market. In general, one might think that the ex post I approach is always superior to an ex post II approach, as the latter loses the competitor in the market.

There are several arguments in a world of uncertainty and limited information, which indicate that that might not generally be the case. One is simply referring to enforcement costs, which tend to be the higher the quicker the analysis has to be delivered. As antitrust authorities' budgets are constrained and a lot of their resources are used for activities other than predation enforcement, this argument might act as an explanation why an antitrust authority would favour an ex post II approach.

A related argument refers to the likelihood of errors. As explained above, it is generally feared that firms might refrain from implementing procompetitive price drops because of the fear that such price drops could be interpreted as predatory and consequently fined. Furthermore, there is a chance that an ex post I approach protects inefficient entrants, as the antitrust authority only

65 See William Landes, “Optimal Sanctions for Antitrust Violations”, University of Chicago Law Review 50, (1983): 652-678.

66 See Becker, n. 64 above.

67 Landes, n. 65 above at 678. In fact, the complete rule says that the "optimal penalty should equal the net harm to persons other than the offender, adjusted upward if the probability of apprehension and conviction is less than one". This second part of the rule becomes relevant in an assessment of optimal enforcement in an imperfect world. See generally John Connor \& Robert Lande (2006), "The Size of Cartel Overcharges", Antitrust Bulletin 51, (2006): 983-1022 and Robert Lande, "Why Antitrust Damage Levels Should be Raised", Loyola Consumer Law Review 16, (2004): 329-345.

68 An alternative definition of harm could be the cost that the violation has imposed on society. That would ignore the distributive effects of a predation strategy (namely, the lower consumer surplus due to higher monopoly profits) and would only focus on the net welfare losses. It can be shown that such an alternative definition of harm typically cannot reach a deterrence effect, as the gains of the violation are typically larger than the optimal harm-based fine. Only if the entrant has a large efficiency advantage would such a definition of harm-based fine lead to a deterrence effect. 
has an incomplete picture of the entrant and its entry attempt. Easterbrook ${ }^{69}$ therefore proposes not to intervene during the possible predation period but to act afterwards, if the old monopoly raises its prices and enjoys monopoly power. ${ }^{70}$

On the other hand, this advice could be very harmful for the consumers if the post-predation period is long (i.e,. the entry barriers are high) and the entrant is lost 'for the market'. ${ }^{11}$ As a consequence, the antitrust authority needs - after an indication of predation is made - a screening system which evaluates how important the entrant could be for the respective industry. If the entry barriers are generally high and an entrant nevertheless managed to enter the market, it can be expected to be more valuable to protect such an entrant than one in an industry with lower entry barriers and more frequent entry attempts.

\subsection{Ex ante, per se rule}

In an ex ante rule approach, the antitrust authority commits itself to a certain entry reaction before an incumbent actually decides to predate. If the antitrust authority credibly announces ex ante (at point $t_{0}^{\text {int }}$ in Figure 3 above) that it would, for instance, force the incumbent to keep its post-entry price for a certain period even after the entrant left the market, the costs of the predation period would rise substantially and recoupment possibilities would decline for the incumbent simultaneously. Hence, assuming that such a rule works frictionless, the incumbent's incentives are altered in a way that makes predation unprofitable and therefore irrational. Consequently, the consumers cannot enjoy the high consumer surplus during the predation phase but instead realise the duopoly consumer surplus from the point of entry to the end of the market. ${ }^{72} \mathrm{~A}$ comparison of the realised welfare with an ex ante, per se rule and an ex post I rule of reason shows that the former is the superior choice as long as (see Section 9.4 for the proof)

$$
\mathrm{CS}^{\text {Duo }}-\mathrm{CS}^{\text {Pred }}>\pi_{\mathrm{E}}^{\text {Pred }}+\pi_{\mathrm{I}}^{\text {Pred }}-\pi_{\mathrm{E}}^{\text {Duo }}-\pi_{\mathrm{I}}^{\text {Duo }} .
$$

The inequality basically says that an ex ante per rule is superior to an ex post I rule of reason as long as the difference between the consumer surplus in duopoly and predation (in the predation period) is larger than the overall producer surplus difference between predation and duopoly (in the predation period). As a consequence, it can be shown that an ex-ante rule is only superior to an ex post I approach if the entrant has a large efficiency advantage over the incumbent. This was basically driven by the fact that with an ex post I approach, the consumers can enjoy the low prices during the predation period and still get - due to ex post I enforcement the duopoly surplus in the post-predation period. With an ex ante approach, the consumers only get the duopoly surplus from the occurrence of entry to the end of the market. Therefore, from an overall welfare perspective, the ex post rule is superior to an ex ante rule as long as the profit losses in the predation period are smaller than the consumer surplus gains in the same period. This is typically the case as long as the entrant's efficiency advantage is not too large.

69 See Easterbrook, n. 58 above.

70 Although it would be thinkable to consider behavioural or structural remedies as part of an ex post II approach (in addition to fines), such options will not be discussed in detail here. The imposition of structural remedies (in the form of divestitures) played a role in the history of predation enforcement, for example in the break-up of Standard Oil (1911), but would typically not be considered as a potentially desirable option nowadays. See Organisation for Economic Co-operation and Development, n. 50 above at 31. Imposing behavioural remedies, however, might be a valuable option within an ex post II approach in order to ease, for example, entry for other competitors (who might build on the experiences or even equipment of the exited entrant). In particular, introducing an ex ante approach as a reaction to a successful predation attempt in an industry would be a possible solution.

71 See Andrew Eckert, "Predatory Pricing and the Speed of Antitrust Enforcement", Review of Industrial Organization 20, (2002): 375-383.

72 In the simple set-up provided by Figure 3, the consumers are better off with an ex ante approach than with a no rule approach as long as the post-predation period is longer than the predation period. 
In an environment of uncertainty and incomplete information, it becomes uncertain whether the antitrust authority is quick enough to rescue the entrant before it is forced to leave the market by a predation strategy. From a consumer perspective, the certain duopoly consumer surplus realised with an ex ante rule has to be compared with the sum of the higher predation consumer surplus and the expectancy value for post-predation period profits. Formally, this condition can be expressed as follows

$$
(\alpha+\beta) \mathrm{CS}^{\text {Duo }}>\alpha \mathrm{CS}^{\text {Pred }}+\beta\left[\theta \mathrm{CS}^{\text {Duo }}+(1-\theta) \mathrm{CS}^{\text {Mono }}\right] .
$$

$\theta$ can be interpreted as the likelihood that the antitrust authority quickly and exactly detects and intervenes against predators. If $\theta=0$, the authority never detects and punishes predators ex post. If $\theta=1$, the authority always detects and punishes predators ex post. As long as the antitrust authority is not too exact or slow in detecting and intervening against predators - or alternatively if high ex post enforcement standards make a conviction unlikely - an ex ante rule leads to a welfare increase. However, if the antitrust authority is relatively efficient in intervening against predators, consumers are still better off with an ex post rule..$^{73}$

Although the ex ante rule might be a valuable enforcement option in theory, much of the practical success of this rule in a world of uncertainty and limited information would depend on its actual design. In that respect, the literature discusses especially two different types of ex ante rules: the 'no post-exit price increase' rule by Baumol and the 'price freezing' rule by Edlin.

\section{- The 'no post-exit price increase' rule}

Baumol $^{74}$ developed his 'no post-exit price increase' rule in 1979, motivated by the publication of Williamson's ${ }^{75}$ 'no post-entry output increase' rule two years earlier. The primary focus of his rule is to avoid reliance on cost-based tests completely. His rule permits price decreases in response to entry but forbids a dominant firm to raise prices again for a considerable period of time (Baumol suggests five years) after the entrant exited the market. The logic of this rule is the following: If a dominant firm only is allowed to raise prices after a certain time period after an entrant exits, the expected monopoly profits are unreachable during this time period. As a consequence, the predation strategy becomes more expensive, and therefore its actual usage becomes more unlikely. In short, Baumol's rule lowers or erases the incentives of the incumbent to select a price that it could not live with in longer terms.

\section{- The 'price freezing' rule}

Edlin's ${ }^{76}$ proposal lies in the spirit of the rules of Baumol and Williamson. He proposes that in markets where an incumbent monopoly enjoys significant advantages over potential entrants, but another firm enters and provides buyers with a substantial discount, "the monopoly should be prevented from responding with substantial price cuts or significant product enhancements until the entrant has had a reasonable time to recover its entry costs and become viable, or until the entrant's share grows enough so that the monopoly loses its dominance" .77 Edlin proposes that if an entrant prices $20 \%$ below an incumbent monopoly, the incumbent's prices

73 Although the consumer welfare approach just sketched provides helpful insights, this paper primarily follows a total welfare approach. In a total welfare approach, the respective inequality changes to the following expression

$$
\begin{gathered}
(\alpha+\beta)\left(\mathrm{CS}^{\text {Duo }}+\pi_{\mathrm{E}}^{\text {Duo }}+\pi_{\mathrm{I}}^{\text {Duo }}\right)>\alpha\left(\mathrm{CS}^{\text {Pred }}+\pi_{\mathrm{E}}^{\text {Pred }}+\pi_{\mathrm{I}}^{\text {Pred }}\right)+ \\
\beta\left[\left(\theta\left(\mathrm{CS}^{\text {Duo }}+\pi_{\mathrm{E}}^{\text {Duo }}+\pi_{\mathrm{I}}^{\text {Duo }}\right)+(1-\theta)\left(\mathrm{CS}^{\text {Mono }}+\pi_{\mathrm{I}}^{\text {Mono }}\right)\right)\right]
\end{gathered}
$$

While the general structure and the interpretation of $\theta$ remains unchanged from the consumer welfare approach, the total welfare inequality incorporates consumer surplus and industry profits.

74 See Baumol, n. 36 above.

75 See Williamson, n. 34 above.

76 See Edlin, n. 31 above.

77 Ibid., at 945. 
will be frozen for 12 to 18 months. If the incumbent violates this behavioural intervention, the entrant can sue successfully for predation without the need to demonstrate below-cost pricing or the opportunity for recoupment.

Although both rules have apparent similarities, an important difference is that Edlin's rule encourages the incumbent to charge lower than monopoly ${ }^{78}$ prices from the start (already in the pre-predation period) in order to discourage entry. ${ }^{79}$ If entry takes place anyway, Edlin's rule offers the entrant some protection against predation attempts by freezing the incumbent's price but does not intent to make predation unprofitable. Therefore, Edlin's proposal must be understood more as an approach to constrain monopoly behaviour generally rather than a rule solely designed to fight predation. Baumol's rule, on the other hand, lies in the spirit of a predation ex ante rule used so far, as his rule tries to make predation unprofitable by artificially extending the costly predation period for the incumbent.

Although applying these rules looks easy and straightforward, there are certainly many challenges in applying them in practice. Edwards ${ }^{80}$ as well as Facey and Ware ${ }^{81}$ argue, for instance, that ex ante rules are not as easy to administer as their creators suggest, as they would require, for each industry, or in each case where a firm develops a monopoly, ongoing micromanagement by the courts or a regulatory agency to determine the appropriate periods of price freezes and to review these determinations. These determinations would likely be subject to lengthy and ongoing litigious and non-litigious arguments between the interested parties. ${ }^{82}$ In other words, enforcement cost as such might be lower than in an ex post approach; however, the monitoring cost might eat away this advantage.

With respect to the necessary monitoring, ex ante rules might run into an institutional problem. As discussed by Geroski ${ }^{83}$, the aim of antitrust authorities is not constantly to oversee the performance of particular markets or senior management decisions, but only to "swing [..] into operation when serious, egregious problems are believed to exist". From that perspective, it is worth considering handing over the possible application of ex ante rules to the responsible regulatory authorities or, alternatively, to increase (further) the scope of antitrust authorities' activities into regulatory-type interventions (such as in the field of merger control).

Another major problem of ex ante rules is that they might also reduce incentives for socially desirable price decreases. "[B]y making price increases difficult, the rule might also make innocent firms leery of cutting prices, for fear of losing their ability to raise them later again". ${ }^{84}$ Edwards shows that this might be a considerable problem, especially in industries in which network effects play an important role.

78 The price the incumbent charges depends on his expectation of the likelihood of entry. If he believes that entry is impossible, he would continue to charge the monopoly price. If entry is immanent, he would charge the duopoly price.

79 As Williamson shows, his 'no post-entry output increase' rule also has positive pre-entry welfare effects.

80 See Edwards, n. 31 at 188.

81 See Brian Facey \& Roger Ware, "Predatory Pricing in Canada, the United States and Europe: Crouching Tiger or Hidden Dragon?", World Competition 26, (2003): 625-650.

82 See Edwards, n. 31 above at 188. Following Elhauge, an application of Edlin's rule would encourage 'cream skimming' where entrants can be protected in price cutting on lucrative sub-markets. Another point of criticism, namely that the incumbent has an incentive to adjust its price immediately before entry, can be solved by using yearly average prices, for example. Another disadvantage of the rule derives from the fact that prices typically underlie many variations over time (with varying motivations). When unexpected cost changes occur, the dominant firm should be allowed to raise prices. As a consequence, the workability of Baumol's rule is relatively low, as the reviewing authorities would have to ensure that a price cut remains in effect for the required period following exit. See Elhauge, n. 60 at 682.

83 Paul Geroski, “Is Competition Policy Worth it?”, Speech manuscript, Competition Commission, London, 2004 at 4 .

84 Organisation for Economic Co-operation and Development, Predatory Pricing, Paris, 1989, 23. 
Another challenge of an ex ante rule is the correct (ex ante) fixing of the number of periods of the rule's effectiveness. Baumol suggests a period of 60 months for his rule; Edlin only 12 to 18 months. In the former case, the duration of the price freeze determines whether predation becomes irrational or not. In the latter case, it depends on assumptions about the time the entrant needs to become established in the market. If the duration is too short, the Baumol rule does not negate all the predation gains and predation might still be a rational strategy.

As a consequence, the choice of the optimal ex ante rule depends on the efficiency of the entrant. As the efficiency of the entrant and the level of fixed costs are likely unknown ex ante, it becomes apparent that an ex ante rule is quite imprecise. Given this fuzziness, ex ante rules can hardly be a suitable general instrument to fight predation. Nevertheless, it is important to recall its positive characteristics, such as quickness and potential to keep the entrant in the market (which therefore has the potential to minimise type II errors). These advantages have to be traded off against the disadvantages, making the application of ex ante rules a socially desirable option if the likelihood of type I errors is low and the likelihood of type II errors is high.

\section{Towards a Policy Framework to Enforce Predation}

The general aim of this contribution is to derive recommendations which can guide antitrust authorities in implementing an efficient predation policy. Consequently, having studied optimal predation enforcement from a theoretical perspective in the preceding sections, the next and final step lies in transforming the key insights into policy recommendations that can be implemented.

The policy relevance of the theoretical analysis can be separated into two channels: refining the current predation enforcement regime, or amending it. While the former channel focuses on an increased role of sanctions within the existing regime (which is applicable for all markets in an economy), the latter suggests implementing an additional enforcement approach for specific industries in which predation is more likely and potentially more harmful than in other industries.

The first channel of improvement deals with the refinement of the current predation enforcement regime. In this respect, the analysis in the preceding sections revealed that the relatively well-developed detection phase in predation enforcement is currently not complemented by an equally well developed intervention phase. If predation enforcement should aim at deterring the use of predation strategies by incumbents, the creation of a substantial threat by credibly committing to optimal fines is pivotal. Although the basic technique to calculate such optimal fines is straightforward, the credibility of such a step might be limited, at least in North America and Australia, where the very high predation enforcement standards would foreclose the effectiveness of fine increases simply because the probability of a conviction is so small. However, the somewhat lower predation enforcement standards in Europe - which even resulted in several convictions of predators in the last couple of years - may provide better possibilities to strengthen the existing (but likely small) deterrence effect by a commitment to optimal fines. Especially the UK Office of Fair Trading seems to follow this general idea by, on the one hand, actively referring to the role of deterrence in predation enforcement and, on the other hand, providing some first guidance on the calculation of harm caused by predation infringements..$^{85}$

Thinking about further ways to improve the enforcement of predation strategies, a comparison of predation enforcement with other antitrust enforcement activities - such as hard core cartel enforcement or merger control - reveals especially two specifics of predation enforcement which need to be considered when developing policy recommendations. First, given the vulnerability of the entrant in a typical predation attack, it is pivotal for an efficient antitrust enforcement to react quickly to possible infringements to keep the entrant in the market. If the antitrust authority is slow or follows an ill-equipped predation enforcement framework, it is likely that the entrant has to leave the market before the authority is able (or wants) to react. As a consequence, the entrant

85 See Office of Fair Trading, Positive Impact - An Initial Evaluation of the Effect of the Competition Enforcement Work Conducted by the OFT, London, 2005. 
is lost as a competitive regulator of the incumbent and consumers are likely to suffer from higher prices or may even have to decide to reduce or abandon the consumption of the respective good or service.

Second, with respect to the creation of a deterrence effect as the basic aim of antitrust enforcement, predation is somewhat more difficult to handle than hard core cartels or horizontal mergers given the significant danger of deterring not only anticompetitive but also procompetitive decreases in price. As procompetitive price decreases are the hallmark of competition, a predation enforcement which is tough but vague runs a high risk of creating a negative deterrence effect and consequently might harm overall welfare. It is essentially this danger that prevents the antitrust enforcers in the United States, Canada or Australia from following a tougher predation enforcement. As a consequence, any attempt to increase the deterrence effect has to consider the danger of discouraging procompetitive price decreases and must therefore delineate clear boundaries of predation enforcement in order to avoid a negative deterrence effect.

Based on these essential preconditions, together with other fundamental insights of the theoretical analysis derived above, the following three-step pre-screening approach as an amendment to the current regime of predation enforcement is proposed:

1. Assessment of incumbency advantages - How difficult is it to get in?

2. Assessment of the potential gains of entry - How desirable is it for society to establish entry?

3. Assessment of antitrust enforcement - How reliable is antitrust enforcement?

The first step of a pre-screening approach aims at identifying industries with difficult entry; the second step addresses whether there are economic reasons why incumbency advantages for these industries are socially desirable. Subsequently, all industries in which entry is difficult but socially desirable are investigated further in a third stage, where the quality of antitrust enforcement determines the optimal predation enforcement option (ex ante versus ex post approach). Before the specifics of the three steps are explained in more detail, Figure 4 gives an overview of the general structure of the proposed framework.

\section{Assessment of incumbency advantages - How difficult is it to get in?}

The starting point of the pre-screening approach is an assessment of the role of incumbency advantages. The basic justifications for such a step are that, on the one hand, significant incumbency advantages are a necessary precondition for the profitability of predation strategies and, on the other hand, they are a good indicator of the desirability of increased competition. Generally, incumbency advantages comprise structural advantages and strategic advantages, whereas the latter group can be subdivided into 'positioning before entry' and 'reaction after entry' moves. Although it is perhaps not possible to quantify all important incumbency advantages in such an assessment, the development of several entry barrier indicators ${ }^{86}$ show that quantifications are possible. Complementary to this structural assessment of industries, previous predation experiences can be used, in the form of stylised facts, to identify industries in which predation might play a role structurally (such as in competition among airlines, busses or ships). Consequently, the result of the first stage should ideally be a list of industries that are characterized by high incumbency advantages and/or an industry in which predation strategies have been an issue historically. All industries that do not meet these criteria are dropped; they do not proceed to the second step of the pre-screening approach.

86 See NERA, Empirical Indicators for Market Investigators, Report prepared for the Office of Fair Trading, Part 1: Main Report, London, 2004. 
Fig. 4. A predation enforcement framework

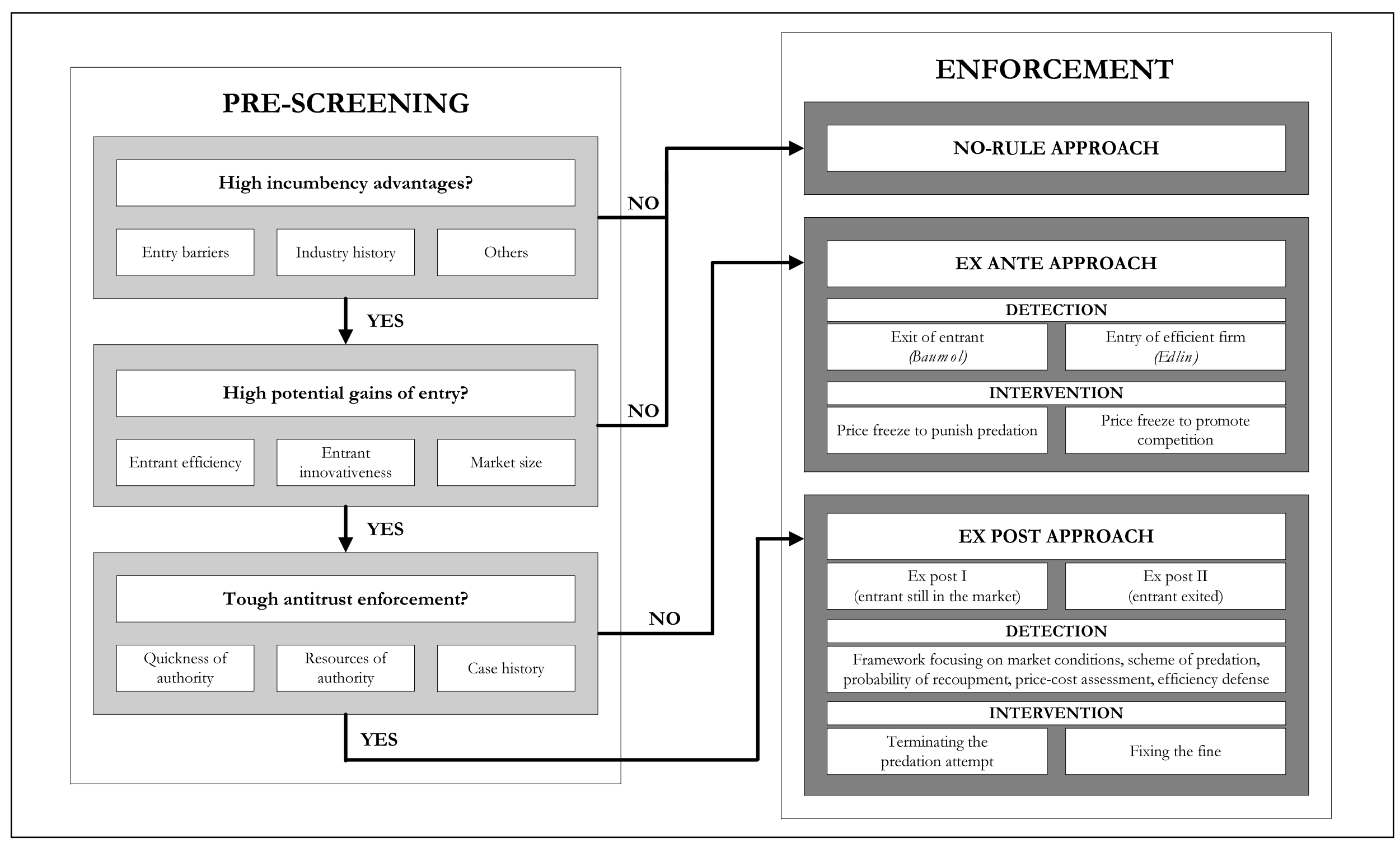




\section{Assessment of potential gains of entry - How desirable is it for society to establish entry?}

The second step of the pre-screening approach assesses the desirability of entry into the industries identified in the first stage of the framework. A full assessment must consider especially two factors: first, whether entry is generally desirable in the industry; second, how important is entry for the development of competition in the industry (i.e., how valuable is the entrant for post-entry competition in the industry). With respect to the first question, the discussion above indicated that the existence of high incumbency advantages as such does not automatically arrive at the conclusion that entry is desirable. On the one hand, competition might not be workable in certain industries in general (or in sub-markets of industries). On the other hand, competition might lead to suboptimal results due to particular market characteristics, such as economies of scale on the supply and/or demand side. In both cases, the conclusion would be that, even if incumbency advantages are high, entry is not desirable from a welfare perspective.

The second factor considers the characteristics of a typical entrant in the industry. If it can be expected that an entrant has either efficiency advantages over the incumbent or other competitive advantages, such as a more innovative business concept, entry is more desirable from a welfare point of view than when an equally efficient entrant enters. Therefore it is, ceteris paribus, more important to rescue a more efficient or more innovative entrant than an entrant who just copies the business concept of the incumbent. In other words, considering the efficiency of the entrant should play an important role in predation cases. Nitsche ${ }^{87}$ supports such a demand by stating that "there should be anti-predation rules that take into account the costs and benefits of entry".

A factor that further puts the focus on the efficiency of the entrant into perspective is market size. In particular, market size needs to be considered in the sense that the welfare contribution of predation enforcement in a large market facing entry of an equally efficient entrant can still be larger (in absolute terms) than that of a more efficient entrant in a smaller market. Although it would be, in principle, desirable to stop predation in both markets, the market size criterion might become relevant when the antitrust authority faces resource constraints and cannot investigate every instance of possible predation. Here a rule of thumb, such as 'try to catch the biggest ones' might guide the proper allocation of resources. Hemphill argues similarly, stating "[w]e should prefer rules that are especially likely to prevent the costliest false negatives (and false positives), for example, by always catching predators who make the most socially harmful price cuts. ${ }^{88}$

\section{Assessment of antitrust enforcement - How reliable is antitrust enforcement?}

The third pre-screening stage has to consider the specifics of antitrust enforcement in the respective jurisdictions. Based on the findings of the previous two stages, one fundamental aim of predation enforcement must be to keep efficient entrants in the market and help them defend themselves against predation attacks by incumbents. As mentioned above, the best way to reach such an aim depends on the qualities of the antitrust authority. If the antitrust authority has a well-equipped budget and is 'smart' and quick ${ }^{89}$, an ex post I approach is the optimal solution for welfare, as it can quickly decide on the most suitable form of antitrust reaction in a predation attempt. If, however, the antitrust authority has a lower budget, has an ill-equipped predation approach or is constrained by restrictive case law (which makes convicting a predator unlikely), it is socially desirable to administer an ex ante approach for selected industries. Although such

87 Nitsche shows in an entry game that introducing ex post predation rules can be detrimental to total welfare as well as to consumer welfare, because incumbents choose a strategic response to the new legal environment. In his model, large incumbents crowd the product space to reduce the number of profitable entry opportunities for rivals. See Rainer Nitsche, On the Effectiveness of Anti-Predation Rules, Working Paper, WZB, Berlin, 2002.

88 See Hemphill, n. 11 above at 1586.

89 A 'smart' antitrust authority constantly keeps record of price and cost data and generally tries to acquire industry-specific knowledge. See Eckert, n. 71 above at 382. 
an approach is typically more inexact in detecting predation, it has the major advantage of keeping the entrant in the market and basically provides it with a chance to compete on fair terms with the incumbent. Furthermore, although in principle the likelihood of antitrust errors is relatively high under the ex ante approach, the pre-screening stages selected for specific industries in which the likelihood of such errors is considerably reduced. In other words, the ex ante approach aims at creating a selective deterrence effect, specifically for those industries in which entry is unlikely but desirable and the standard antitrust enforcement is unlikely to help.

\section{Conclusion}

The major interest of antitrust law and economics with respect to predation strategies has been largely twofold. On the one hand, there has been a lively discussion on the question whether predation can basically be a rational strategy for an incumbent facing an entry threat. On the other hand, research has focused on the problem of how an antitrust authority should detect predation strategies and especially distinguish such abuses from socially desirable, procompetitive behaviour. However, compared to other areas of antitrust policy such as hard core cartel enforcement or merger control, surprisingly little research has been devoted to the subsequent third stage in antitrust analysis: intervention. This stage acknowledges the necessity of appropriate detection rules for efficient antitrust enforcement, but it uses these insights to answer the complementary question of how these rules should be linked to punishment with a pecuniary fine and/or the imposition of behavioural remedies.

Against this background, the paper aimed at developing a framework to enforce anti-predation rules that explicitly takes the intervention stage into account. Following a characterisation and rationalisation of predation, the welfare effects of predation were studied. Given the key finding that predation can be a rational business strategy with negative implications on overall welfare, research with respect to the detection of predation was reviewed. However, given the fact that detecting is a necessary but not sufficient condition for 'enforcing', the intervention options against predators were analyzed subsequently. The analysis differentiated between a no rule approach, an ex post rule of reason and an ex ante per se rule. It was shown that no policy option dominates the others and that the welfare optimal policy response depends on several industry and market characteristics such as the level of the incumbency advantages, the level of the gains of entry for society or the specifics of antitrust enforcement in the respective jurisdiction. Subsequently, the key insights of the analysis were incorporated into the development of a framework to enforce anti-predation rules which aims at increasing the deterrence effect of predation strategies without biasing the fundamentally important incentives of firms for procompetitive price decreases.

In particular, the proposed framework is separated into two channels: refining the current predation enforcement regime, and amending it. With respect to the refinement of the current enforcement regime, it was found that the proposal to increase the fines for detected and convicted predators might probably be too weak to significantly amplify the deterrence effect, basically due to the very low probability of conviction. As a consequence, the introduction of a pre-screening approach was proposed, which aims at identifying industries in which entry is difficult but desirable and a predation strategy might be a suitable instrument for an incumbent to fight such occasional entry attempts. In those industries, it is advisable to reduce the high standard of proof in predation enforcement, as its basic justification - the danger to create a negative deterrence effect - is significantly reduced. If the antitrust authority is tough and not restricted by case law, such a deterrence effect might be reached with the standard ex post approach. However, if the antitrust authority is weak, the best way to amplify the deterrence effect is by implementing an ex ante rule, such as the one proposed by Edlin. To put it simply, the art of predation enforcement lies in the creation of a selective deterrence effect which discourages anticompetitive price cuts 'in suspicious industries' but leaves the incentives of firms to implement procompetitive price cuts unaffected. 


\section{Annex}

\subsection{Proof of Inequality (1) in Section 4.}

As discussed in section 4, an initial welfare assessment has to compare the welfare situation of a successful predation strategy against the welfare realised if the monopoly situation in the prepredation period would have continued. Based on the setup shown in Figure 3, the welfare if predation is successful,

$$
\begin{aligned}
& \mathrm{W}_{\text {Predation successful }}=\left[\left(\mathrm{t}^{\text {exit }}-\mathrm{t}^{\text {entry }}\right)\left(\mathrm{CS}^{\text {Pred }}\right)\right]+\left[\left(\mathrm{t}^{\text {end }}-\mathrm{t}^{\text {exit }}\right)\left(\mathrm{CS}^{\text {Mono }}\right)\right]+ \\
& \left\lfloor\left(t^{\text {exit }}-t^{\text {entry }}\right)\left(\pi_{\mathrm{E}}^{\text {Pred }}\right)\right]+\left\lfloor\left(t^{\text {exit }}-t^{\text {entry }}\right)\left(\pi_{\mathrm{I}}^{\text {Pred }}\right)+\left(t^{\text {end }}-t^{\text {exit }}\right)\left(\pi_{I}^{\text {Mono }}\right)\right] \text {, }
\end{aligned}
$$

has to be larger than the welfare realised in the case of continuous monopoly,

$$
\begin{gathered}
\mathrm{W}_{\text {Continuous Monopoly }}=\left[\left(\mathrm{t}^{\text {exit }}-\mathrm{t}^{\text {entry }}\right)\left(\mathrm{CS}^{\text {Mono }}\right)\right]+\left[\left(\mathrm{t}^{\text {end }}-\mathrm{t}^{\text {exit }}\right)\left(\mathrm{CS}^{\text {Mono }}\right)\right]+ \\
{\left[\left(\mathrm{t}^{\text {exit }}-\mathrm{t}^{\text {entry }}\right)\left(\pi_{\mathrm{I}}^{\text {Mono }}\right)\right]+\left[\left(\mathrm{t}^{\text {end }}-\mathrm{t}^{\text {exit }}\right)\left(\pi_{\mathrm{I}}^{\text {Mono }}\right)\right] .}
\end{gathered}
$$

Substituting $\left(\mathrm{t}^{\text {exit }}-\mathrm{t}^{\text {enrty }}\right)=\alpha$ and $\left(\mathrm{t}^{\text {end }}-\mathrm{t}^{\text {exit }}\right)=\beta$ and simplifying both expressions leads to

$$
\begin{gathered}
\mathrm{W}_{\text {Continuous Monopoly }}=\alpha\left(\mathrm{CS}^{\text {Mono }}+\pi_{\mathrm{I}}^{\mathrm{Mono}}\right) \\
\mathrm{W}_{\text {Predation successful }}=\alpha\left(\mathrm{CS}^{\text {Pred }}+\pi_{\mathrm{E}}^{\text {Pred }}+\pi_{\mathrm{I}}^{\text {Pred }}\right) .
\end{gathered}
$$

Further simplifying and rearranging leads to

$$
\mathrm{CS}^{\text {Pred }}-\mathrm{CS}^{\text {Mono }}>\pi_{\mathrm{I}}^{\text {Mono }}-\left(\pi_{\mathrm{E}}^{\text {Pred }}+\pi_{\mathrm{I}}^{\text {Pred }}\right) \text {. }
$$

\subsection{Proof of Inequality (2) in Section 4.}

As discussed in section 4, antitrust rules and interventions increase welfare as long as the overall welfare realised with such interventions,

$$
\begin{aligned}
& \mathrm{W}_{\text {Antitrust }}=\left[\left(\mathrm{t}^{\text {exit }}-\mathrm{t}^{\text {entry }}\right)\left(\mathrm{CS}^{\text {Pred }}\right)+\left(\mathrm{t}^{\text {end }}-\mathrm{t}^{\text {exit }}\right)\left(\mathrm{CS}^{\text {Duo }}\right)\right]+ \\
& \left(\left(t^{\text {exit }}-t^{\text {entry }}\right)\left(\pi_{\mathrm{E}}^{\text {Pred }}\right)+\left(t^{\text {end }}-t^{\text {exit }}\right)\left(\pi_{\mathrm{E}}^{\text {Duo }}\right)\right]+ \\
& \left.\|\left(t^{\text {exit }}-t^{\text {entry }}\right)\left(\pi_{\mathrm{I}}^{\text {Pred }}\right)+\left(t^{\text {end }}-t^{\text {exit }}\right)\left(\pi_{I}^{\text {Duo }}\right)\right] \text {, }
\end{aligned}
$$

is larger than the welfare realised when the incumbent can successfully apply a predation strategy

$$
\begin{aligned}
& \mathrm{W}_{\text {No Antitrust }}=\left[\left(\mathrm{t}^{\text {exit }}-\mathrm{t}^{\text {entry }}\right)\left(\mathrm{CS}^{\text {Pred }}\right)\right]+\left[\left(\mathrm{t}^{\text {end }}-\mathrm{t}^{\text {exit }}\right)\left(\mathrm{CS}^{\text {Mono }}\right)\right]+ \\
& {\left[\left(t^{\text {exit }}-t^{\text {entry }}\right)\left(\pi_{E}^{\text {Pred }}\right)\right]+\left[\left(t^{\text {exit }}-t^{\text {entry }}\right)\left(\pi_{\mathrm{I}}^{\text {Pred }}\right)+\left(t^{\text {end }}-t^{\text {exit }}\right)\left(\pi_{I}^{\text {Mono }}\right)\right] .}
\end{aligned}
$$

Substituting $\left(t^{\text {exit }}-t^{\text {enrty }}\right)=\alpha$ and $\left(t^{\text {end }}-t^{\text {exit }}\right)=\beta$ and simplifying both expressions leads to

$$
\begin{gathered}
\mathrm{W}_{\text {No Antitrust }}=\beta\left(\mathrm{CS}^{\text {Mono }}+\pi_{\mathrm{I}}^{\text {Mono }}\right), \\
\mathrm{W}_{\text {Antitrust }}=\beta\left(\mathrm{CS}^{\text {Duo }}+\pi_{\mathrm{E}}^{\text {Duo }}+\pi_{\mathrm{I}}^{\text {Duo }}\right) .
\end{gathered}
$$

Further simplifying and rearranging leads to

$$
\mathrm{CS}^{\text {Duo }}-\mathrm{CS}^{\text {Mono }}>\pi_{\mathrm{I}}^{\text {Mono }}-\left(\pi_{\mathrm{E}}^{\text {Duo }}+\pi_{\mathrm{I}}^{\text {Duo }}\right) .
$$




\subsection{Proof of Inequalities (5) and (6) in Section 6.2.}

As discussed in section 6.2., optimal fines can be calculated on a gain-basis and on a harm-basis. In the following, proofs for both fines are provided.

\section{Optimal gain-based fine}

The optimal gain-based fine for an antitrust violation is equal to the additional gain the offender realises due to its misbehaviour. In the setup of Figure 3, the optimal fine is therefore defined as the difference between the incumbent's overall profits realised under successful predation

$$
\pi_{\mathrm{I}}^{\text {Pred }}=\left[\left(\mathrm{t}^{\text {exit }}-\mathrm{t}^{\text {entry }}\right)\left(\pi_{\mathrm{I}}^{\text {Pred }}\right)\right]+\left[\left(\mathrm{t}^{\text {end }}-\mathrm{t}^{\text {exit }}\right)\left(\pi_{\mathrm{I}}^{\text {Mono }}\right)\right]
$$

and the incumbent's profit if it accommodates the entrant

$$
\pi_{\mathrm{I}}^{\text {Duo }}=\left[\left(\mathrm{t}^{\text {exit }}-\mathrm{t}^{\text {entry }}\right)\left(\pi_{\mathrm{I}}^{\text {Duo }}\right)\right]+\left[\left(\mathrm{t}^{\text {emd }}-\mathrm{t}^{\text {exit }}\right)\left(\pi_{\mathrm{I}}^{\text {Duo }}\right)\right] .
$$

Substituting $\left(t^{\text {exit }}-t^{\text {enrty }}\right)=\alpha$ and $\left(t^{\text {end }}-t^{\text {exit }}\right)=\beta$ and simplifying both expressions leads to

$$
\begin{aligned}
& \pi_{\mathrm{I}}^{\text {Pred }}=\beta \pi_{\mathrm{I}}^{\text {Mono }}+\alpha \pi_{\mathrm{I}}^{\text {Pred }}, \\
& \pi_{\mathrm{I}}^{\text {Duo }}=\beta \pi_{\mathrm{I}}^{\text {Duo }}+\alpha \pi_{\mathrm{I}}^{\text {Duo }} .
\end{aligned}
$$

Generally, the optimal gain-based fine is $\mathrm{F}_{\text {Gain based }}=\pi_{\mathrm{I}}^{\text {Pred }}-\pi_{\mathrm{I}}^{\text {Duo }}$. Using the expressions above leads to the following optimal gain-based fine:

$$
\mathrm{F}_{\text {Gain based }}=\beta\left(\pi_{\mathrm{I}}^{\text {Mono }}-\pi_{\mathrm{I}}^{\text {Duo }}\right)+\alpha\left(\pi_{\mathrm{I}}^{\text {Pred }}-\pi_{\mathrm{I}}^{\text {Duo }}\right) .
$$

\section{Optimal harm-based fine}

As explained in the text, the optimal harm-based fine refers to the 'net harm to others' caused by the violation. In the predation period, harm is therefore given by the sum of the difference between the duopoly and the predation consumer surpluses and the difference between the entrant's duopoly and predation profits

$$
\operatorname{Harm}_{\alpha}=\alpha\left[\left(\mathrm{CS}^{\text {Duo }}-\mathrm{CS}^{\text {Pred }}\right)+\left(\pi_{\mathrm{E}}^{\text {Duo }}-\pi_{\mathrm{E}}^{\text {Pred }}\right)\right] .
$$

If predation is successful, the net harm to others is given by the difference between the duopoly and the monopoly consumer surpluses and the entrant's duopoly profits (it would have earned without a successful predation strategy)

$$
\operatorname{Harm}_{\beta}=\beta\left[\left(\mathrm{CS}^{\text {Duo }}-\mathrm{CS}^{\text {Mono }}\right)+\pi_{\mathrm{E}}^{\text {Duo }}\right] .
$$

The optimal harm-based fine is therefore given by

$$
\mathrm{F}_{\text {Harm based }}=\alpha\left[\left(\mathrm{CS}^{\text {Duo }}-\mathrm{CS}^{\text {Pred }}\right)+\left(\pi_{\mathrm{E}}^{\text {Duo }}-\pi_{\mathrm{E}}^{\text {Pred }}\right)\right]+\beta\left[\left(\mathrm{CS}^{\text {Duo }}-\mathrm{CS}^{\mathrm{Mono}}\right)+\pi_{\mathrm{E}}^{\text {Duo }}\right]
$$

An alternative definition of harm could be the cost that the violation has imposed on society. Such harm would ignore the distributive effects of a predation strategy (namely, the lower consumer surplus due to higher monopoly profits) and would only focus on the net welfare losses, which can be defined as the difference between the welfare level which would have been realised if the incumbent has accommodated the entrant

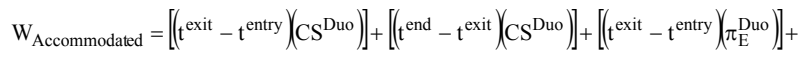

$$
\begin{aligned}
& \left(\left(t^{\text {end }}-t^{\text {exit }}\right)\left(\pi_{\mathrm{E}}^{\text {Duo }}\right)\right]+\left[\left(t^{\text {exit }}-t^{\text {entry }}\right)\left(\pi_{\mathrm{I}}^{\text {Duo }}\right)\right]+\left\lfloor\left(t^{\text {end }}-t^{\text {exit }}\right)\left(\pi_{\mathrm{I}}^{\text {Duo }}\right)\right] \text {, }
\end{aligned}
$$

and the welfare level which would have been realised if the incumbent has successfully applied a predation strategy 


$$
\left[\left(t^{\text {exit }}-t^{\text {entry }}\right)\left(\pi_{E}^{\text {Pred }}\right)\right]+\left[\left(t^{\text {exit }}-t^{\text {entry }}\right)\left(\pi_{\mathrm{I}}^{\text {Pred }}\right)+\left(t^{\text {end }}-t^{\text {exit }}\right)\left(\pi_{I}^{\text {Mono }}\right)\right] .
$$

Substituting $\left(t^{\text {exit }}-t^{\text {enrty }}\right)=\alpha$ and $\left(t^{\text {end }}-t^{\text {exit }}\right)=\beta$ and simplifying both expressions leads to

$$
\begin{gathered}
\mathrm{W}_{\text {Accommodated }}=(\alpha+\beta)\left(\mathrm{CS}^{\text {Duo }}+\pi_{\mathrm{E}}^{\text {Duo }}+\pi_{\mathrm{I}}^{\text {Duo }}\right), \\
\mathrm{W}_{\text {Predation successful }}=\alpha\left(\mathrm{CS}^{\text {Pred }}+\pi_{\mathrm{E}}^{\text {Pred }}+\pi_{\mathrm{I}}^{\text {Pred }}\right)+\beta\left(\mathrm{CS}^{\text {Mono }}+\pi_{\mathrm{I}}^{\text {Mono }}\right) .
\end{gathered}
$$

The optimal harm-based fine would then be given by

$$
\begin{gathered}
\mathrm{F}_{\text {Harm based }}=(\alpha+\beta)\left(\mathrm{CS}^{\text {Duo }}+\pi_{\mathrm{E}}^{\text {Duo }}+\pi_{\mathrm{I}}^{\text {Duo }}\right)- \\
\left\{\alpha\left(\mathrm{CS}^{\text {Pred }}+\pi_{\mathrm{E}}^{\text {Pred }}+\pi_{\mathrm{I}}^{\text {Pred }}\right)+\beta\left(\mathrm{CS}^{\text {Mono }}+\pi_{\mathrm{I}}^{\text {Mono }}\right)\right\} .
\end{gathered}
$$

It can be shown that such an alternative definition of harm typically cannot reach a deterrence effect, as the gains of the violation are typically greater than the 'optimal' harm-based fine. Only if the entrant has a large efficiency advantage would this definition of a harm-based fine lead to a deterrence effect.

\subsection{Proof of Inequality (7) in Section 6.3.}

As discussed in section 6.3, an alternative to ex post antitrust rules is ex ante antitrust rules. If such rules work frictionless they turn predation into an unprofitable strategy before it is actually played by the incumbent. Consequently, the entrant will be accommodated under such a regime.

Ex ante rules are superior to ex post rules if the welfare realised under the former regime,

$$
\begin{gathered}
\mathrm{W}_{\text {Ex-ante rule }}=\left[\left(\mathrm{t}^{\text {exit }}-\mathrm{t}^{\text {entry }}\right)\left(\mathrm{CS}^{\text {Duo }}\right)+\left(\mathrm{t}^{\text {end }}-\mathrm{t}^{\text {exit }}\right)\left(\mathrm{CS}^{\text {Duo }}\right)\right]+ \\
{\left[\left(\mathrm{t}^{\text {exit }}-\mathrm{t}^{\text {entry }}\right)\left(\pi_{\mathrm{E}}^{\text {Duo }}\right)+\left(\mathrm{t}^{\text {end }}-\mathrm{t}^{\text {exit }}\right)\left(\pi_{\mathrm{E}}^{\text {Duo }}\right)\right]+} \\
{\left[\left(\mathrm{t}^{\text {exit }}-\mathrm{t}^{\text {entry }}\right)\left(\pi_{\mathrm{I}}^{\text {Duo }}\right)+\left(\mathrm{t}^{\text {end }}-\mathrm{t}^{\text {exit }}\right)\left(\pi_{\mathrm{I}}^{\text {Duo }}\right)\right] .}
\end{gathered}
$$

is larger than the welfare realised under an ex post regime,

$$
\begin{gathered}
W_{\text {Ex }- \text { post rule }}=\left[\left(t^{\text {exit }}-t^{\text {entry }}\right)\left(\mathrm{CS}^{\text {Pred }}\right)+\left(t^{\text {end }}-t^{\text {exit }}\right)\left(\mathrm{CS}^{\text {Duo }}\right)\right]+ \\
{\left[\left(t^{\text {exit }}-t^{\text {entry }}\right)\left(\pi_{E}^{\text {Pred }}\right)+\left(t^{\text {end }}-t^{\text {exit }}\right)\left(\pi_{E}^{\text {Duo }}\right)\right]+} \\
{\left[\left(t^{\text {exit }}-t^{\text {entry }}\right)\left(\pi_{\mathrm{I}}^{\text {Pred }}\right)+\left(t^{\text {end }}-t^{\text {exit }}\right)\left(\pi_{\mathrm{I}}^{\text {Duo }}\right)\right] .}
\end{gathered}
$$

Substituting $\left(\mathrm{t}^{\text {exit }}-\mathrm{t}^{\text {enrty }}\right)=\alpha$ and $\left(\mathrm{t}^{\text {end }}-\mathrm{t}^{\text {exit }}\right)=\beta$ and simplifying both expressions leads to

$$
\begin{gathered}
\mathrm{W}_{\text {Ex-anterule }}=\alpha\left(\mathrm{CS}^{\text {Duo }}+\pi_{\mathrm{E}}^{\text {Duo }}+\pi_{\mathrm{I}}^{\text {Duo }}\right), \\
\mathrm{W}_{\text {Ex-post rule }}=\alpha\left(\mathrm{CS}^{\text {Pred }}+\pi_{\mathrm{E}}^{\text {Pred }}+\pi_{\mathrm{I}}^{\text {Pred }}\right) .
\end{gathered}
$$

Further simplifying and rearranging leads to

$$
\mathrm{CS}^{\text {Duo }}-\mathrm{CS}^{\text {Pred }}>\pi_{\mathrm{E}}^{\text {Pred }}+\pi_{\mathrm{I}}^{\text {Pred }}-\pi_{\mathrm{E}}^{\text {Duo }}-\pi_{\mathrm{I}}^{\text {Duo }} .
$$

